\title{
Food and Ornament: Use of Shellfish at Ifri Oudadane, a Holocene Settlement in NE Morocco
}

\author{
Rainer Hutterer • Oskar Schröder • Jörg Linstädter
}

Accepted: 2 September 2020 / Published online: 9 October 2020

(C) The Author(s) 2020

\begin{abstract}
Recent excavations of Ifri Oudadane, a prehistoric rockshelter on the Mediterranean coast of NW Morocco, yielded a rich marine and terrestrial fauna. We present an analysis of the shellfish remains (exoskeleton-bearing aquatic invertebrates) from the 2011 trench, covering the Epipaleolithic and Early Neolithic levels. A total of 4,415 liters of sediment contained 8,749 specimens (MNI) of at least 40 species of shellfish: 12 bivalves, 24 gastropods, one tusk shell, barnacles, crabs, and sea urchins. The mean abundance of shellfish was 2 MNI per liter. Limpets (Patellidae), topshells (Trochidae), mussels (Mytilidae), and rockshells (Muricidae) formed $98 \%$ of the total mollusk fauna and were part of the diet; limpets prevailed in Epipaleolithic levels and topshells in Neolithic ones. Evidence was found for a systematic butchering of topshells (Phorcus turbinatus): the shells in Epipaleolithic levels were mostly smashed while
\end{abstract}

\section{R. Hutterer}

Zoologisches Forschungsmuseum Alexander Koenig,

Adenauerallee 160, 53113 Bonn, Germany

e-mail: r.hutterer@leibniz-zfmk.de

O. Schröder

Senckenberg Forschungsinstitut und Naturmuseum Frankfurt, Sektion Entomologie III, Mertonstraße 17-21, 60325 Frankfurt a. M., Germany

J. Linstädter $(\bowtie)$

Deutsches Archäologisches Institut, Kommission für Archäologie Außereuropäischer Kulturen, Dürenstr. 35-37, 53173 Bonn, Germany

e-mail: joerg.linstaedter@ dainst.de topshells in Neolithic levels were usually topped in a uniform way. Seven species of mollusks showed traces of manipulation and were used as ornament or tools. Species used as food, such as limpets, topshells, and mussels, never show any indications of being used as ornament or tools, and the mollusks that were used as jewelry or tools were not part of the diet.

Résumé Les récentes fouilles de l'abri préhistorique Ifri Oudadane (côte méditerranéenne du nord-ouest du Maroc) ont permis de découvrir une riche faune marine et terrestre. Nous présentons ici une analyse des coquillages de la fouille de 2011 couvrant les niveaux épipaléolithique et néolithique ancien. Un total de 4415 litres de sédiments contenait 8749 spécimens (MNI) de 37 espèces de coquillages: 12 bivalves, 24 gastéropodes, 1 défense, des balanes, des crabes et des oursins. L'abondance moyenne des mollusques était de 2 NMI par litre. Les patelles (Patellidae), les gastéropodes (Trochidae), les moules (Mytilidae) et les coquilles de roche (Muricidae) formaient $98 \%$ de la faune totale des mollusques et sont considérées comme faisant partie du régime alimentaire. Les patelles prédominaient à l'époque épipaléolithique et les gastéropodes au néolithique. On a trouvé des preuves d'un dépeçage systématique des gastéropodes Phorcus turbinatus; les coquilles des niveaux épipaléolithiques étaient le plus souvent écrasées tandis que les coquilles supérieures des niveaux néolithiques étaient généralement surmontées de manière uniforme. Sept espèces de mollusques présentaient des traces de manipulation et étaient utilisées comme parure ou outil. Les 
espèces utilisées comme nourriture, telles que les patelles, les gastéropodes et les moules, ne présentent jamais d'indications d'utilisation comme parure ou outil, et les mollusques utilisés comme parure ou outil ne faisaient pas partie du régime alimentaire. En plus des gastéropodes et des vertébrés terrestres, les mollusques et crustacés constituent une part importante de l'alimentation de ces groupes.

Keywords Marine shellfish · Consumption · Ornaments $\cdot$ Neolithic $\cdot$ Epipaleolithic

\section{Introduction}

Coastal areas have played a significant role in the networks of exchange that included trade, migration, and transfer of knowledge. It is therefore not surprising that many technical innovations in NW Africa appear for the first time on Morocco's Mediterranean coast. These included, for example, pottery (Linstädter and Wagner 2013), and the first evidence of domestic animals and cultivated plants (Morales et al. 2013). In general, coastlands attracted early human settlements because they offered suitable raw materials, such as rocks for the production of tools and jewelry (flint, amber); and the remains of marine life were also used for the production of tools and jewelry (mussel shells, bones), pigments (purple), as well as fuel and construction material (e.g., driftwood). Coastal areas are also of utmost importance for humans as a source of food, including both plant and animal resources. Here, the entire range of animal life can be used, from invertebrates (mussels, snails, crustaceans) to fish, reptiles (turtles), seabirds (meat, eggs), and marine mammals (whales, seals, etc.).

Studies of archaeological sites near the coast date back to the mid-nineteenth century. Due to their size, the large piles of mussel shells in Europe attracted the interests of researchers. They were first described by the Danish zoologist Johann Japetus Smith Steenstrup (1813-1887) and were called køkkenmøddinger. However, he considered them to be natural formations. Later, archaeologist Asmussen Worsaae found artifacts and fireplaces in these køkkenmøddinger and was able to prove that they were of anthropogenic origin. In subsequent years, similar features were identified worldwide (North Africa, Peru, Portugal, USA). However, this also led to a greater variety of terms. In the USA, the case of Damariscotta, Maine, 1886, was referred to as Whaleback Shell Midden and, in the Arabic-speaking world, the term Rammadiyat (Arabic: ash heap) was used as in the case of SMH-1, Hergla, Tunisia (Mulazzani et al. 2016). The term, concheiro, was coined by Portuguese archaeologist, Carlos Ribeiro (1813-1882), to refer to such shell mounds. One of the most famous concheiros is Muge, north of Lisbon. A term frequently encountered today is escargotière. It is mainly used in Frenchspeaking countries both for deposits of marine and terrestrial mollusks. Several conference proceedings, site reports, reviews, and articles have been published in recent years which provide an overview of the state of research on the exploitation of marine resources especially mollusks (Bar-Yosef Mayer 2005; Bicho et al. 2011; Cantillo et al. 2014; Colonese et al. 2011; Stoetzel et al. 2014; Torregrose Giménez et al. 2011).

The material studied in the present paper comes from Ifri Oudadane, a prehistoric rockshelter on the Mediterranean coast of NW Morocco. The site was discovered in 2005 during a survey accompanying the construction of a new road from Nador to Al Hoceima. The site was excavated between 2006 and 2011 and has since turned out to be one of the most important archaeological sites in North Africa, covering a time range between 11 and $5.7 \mathrm{ka} \mathrm{cal} \mathrm{BP}$ (Linstädter and Kehl 2012). The Neolithic and Epipaleolithic levels contained a rich flora, including domestic plants (Morales et al. 2013; Zapata et al. 2013), and fauna remains that comprised marine and terrestrial vertebrates (Roski 2015, 2018) and invertebrates (Hutterer et al. 2014). The pottery was published by Linstädter and Wagner (2013) and the lithic industry by Linstädter et al. (2015). The present study deals with the mollusks and their use in this Neolithic-Epipaleolithic settlement. The paper focuses on three aspects:

1. The identification of the diversity of marine resources, with a particular focus on marine invertebrates, in the diet of late hunter-gatherers and early food producers.

2. Analysis of a temporal change in shell sizes.

3. Assessment of the importance of shells in the production of tools and ornaments.

Study Site

Ifri Oudadane is located in a coastal cliff of marble, about $50 \mathrm{~m}$ above the present-day shoreline (Fig. 1). The rockshelter opens to the seaside. Today, the shelter is cut by the recently built coastal road from the adjacent 


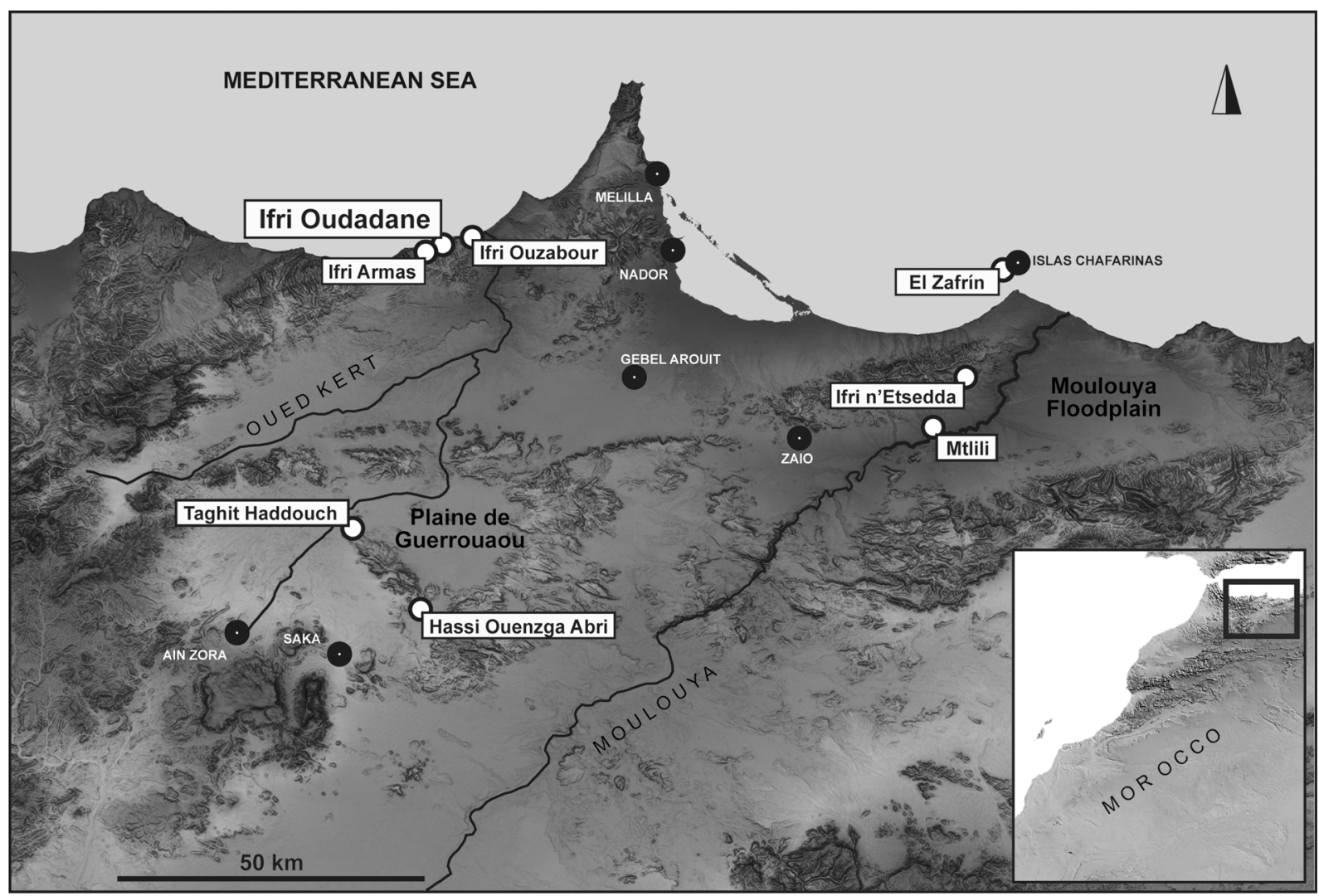

Fig. 1 Study area and the position of Ifri Oudadane, highlighted by larger letters

mountain range. As the direct surroundings of the site are now covered by road debris, the previous topography is hard to imagine. To the south, the terrain rises steeply to more than $150 \mathrm{~m}$ above sea level and leads to a plateau covered by sandy Messinian marls. The rockshelter was formed by marine abrasion during a former high tide in sea level and is about $5 \mathrm{~m}$ high and $15 \mathrm{~m}$ wide. Evidence for a corresponding sea level high tide is provided by beachrock deposits that partially filled the adjacent shelter of Ifri Armas, located on the same altitude, about $6 \mathrm{~km}$ to the west of Ifri Oudadane (Linstädter 2011).

Four field campaigns were carried out in the years 2006, 2007, 2010, and 2011, during which a total area of $12 \mathrm{~m}^{2}$ was excavated. Road debris had to be removed from the surroundings of the site and the shelter itself before the archaeological excavations could be conducted. The thickness of the debris increased from a few centimeters in the southwest up to $1 \mathrm{~m}$ in the northeast. Due to the uneven bedrock, the thickness of the archaeological deposit ranged between 1 and $1.8 \mathrm{~m}$. The excavation was carried out in spits of $5 \mathrm{~cm}$. After removing each spit, the excavated surface was drawn, and the position of the artifacts was measured in three dimensions. A detailed study of the stratigraphy of Ifri Oudadane was published by Linstädter and Kehl (2012). In summary, the archaeological deposits of Ifri Oudadane are up to $2 \mathrm{~m}$ thick and cover a timespan of more than 5,000 years. Records from the Epipaleolithic up to the Late Neolithic are preserved. From $7.6 \mathrm{ka} \mathrm{cal}$ BP onward, a Neolithic level emerged that includes evidence of domesticated animals and plants (Morales et al. 2013). The Epipaleolithic and Neolithic deposits are divided into subunits. Furthermore, the excellent preservation of organic materials enabled a detailed environmental reconstruction (Zapata et al. 2013).

In order to understand the stratigraphical sequence, the excavation area was divided into several trenches or sections. Section CE displays best the archaeological sequence of Ifri Oudadane (Linstädter and Kehl 2012, fig. 2). The results of sedimentological, geochemical, and micromorphological analyses, the distribution of archaeological material, such as pottery, the change of lithic raw material, and radiocarbon data revealed five human occupation phases (Linstädter and Kehl 2012). 
Particularly significant is the transition from more homogeneous sediment at the bottom, representing the Epipaleolithic occupation of the site, to three early Neolithic phases and one late Neolithic settlement event. Then, there is a "fumier-like" sediment on top, formed after the Neolithic occupation. The term "fumier" refers to anthropogenic sediments with an extremely high proportion of animal excrement [fumier (French): dung], a result of the recent use of the site (Angelucci et al. 2009).

The occupation started with the Epipaleolithic at around $11 \mathrm{ka}$ cal BP. This approximately 1 -m-thick deposit comprises the remains of the last huntergatherer society of the region. In addition to artifacts associated with hunting and gathering activities, the archaeological assemblage provides substantial evidence for the exploitation of maritime resources, including fishing and consumption of mussels. The sparse lithic material consists mainly of unspecific flakes, as well as some notched flakes and blades, scrapers, and typical Epipaleolithic backed points. The most recent Epipaleolithic ${ }^{14} \mathrm{C}$-age of $7.632 \pm 29$ cal BP (Beta316137), taken from a seed of Chamaeorops humilis, provides no significant temporal gap to the earliest Neolithic age of $7.610 \pm 40 \mathrm{cal}$ BP (BETA 295779) obtained from a domesticated lentil. Therefore, a continuity between the Epipaleolithic and the Early Neolithic can be assumed.

The Early Neolithic is subdivided into three phases: Early Neolithic A to C (ENA, ENB, and ENC). The initial ENA horizon, only present in the northern part of the excavation area, is associated with the $7.610 \pm 40 \mathrm{cal}$ BP (BETA 295779) age and is characterized by the appearance of Cardium-decorated pottery and large notched blades indicating changes in the lithic tool production. An emerging bone industry is documented by the occurrence of bone needles. However, the most remarkable change is the appearance of domesticated species that mark a more diversified subsistence strategy (Morales et al. 2013). The use of maritime resources was still an important factor in the Early Neolithic. The increased accumulation rate in this period suggests a more dynamic occupation of the shelter or changes in subsistence strategy. The subsequent ENB was the main occupation phase. Visible in all sections, this phase is represented across the entire excavation. Most of the radiocarbon ages were made on short-lived samples of cereals and legumes, and these date the phase between
7.1 and $6.7 \mathrm{ka}$ cal BP. After this, accumulation rates increased again, and the presence of calcite spherulites indicate intensive penning of ovicaprids inside the shelter (Linstädter and Kehl 2012). Although different cereals and legumes are identified, the use of maritime resources still plays an important role in the diet of the shelter's occupant.

The rockshelter is rich in archaeological materials. ENA and ENB are distinguishable from one another based on pottery decoration (we will return to this later). Furthermore, a varied bone industry, including points, needles, spatulas, and a ring, appeared in the ENB assemblage. The ENC, dated between 6.6 and $6.3 \mathrm{ka} \mathrm{cal} \mathrm{BP}$, is characterized by a shallow deposit and a few finds suggesting a decline of settlement intensity. As Late Neolithic materials are to be found scattered on the surface, they are not sufficient to form a proper layer. Erosion processes seem to have severely affected the integrity of the Late Neolithic occupation phase. A charcoal sample, which yielded an age of $5.763 \pm$ 80 cal BP (KIA 39296), seems to fit well with the Late Neolithic of the area (Linstädter 2008), but the archaeological material of the ENC and the Late Neolithic are not clearly separated.

\section{Archaeological Background}

The Neolithic transition of western Mediterranean appears as a complex interplay of natural environment, climate change, and population dynamics. This process was characterized by distinct regional trends. Numerous studies have been dedicated to identifying the course of this transition and the character of the Early Neolithic in various regions: e.g., Valencia and its surroundings (Bernabeu Aubán et al. 1999, Bernabeu Aubán et al. 2009; Cámalich Massieu and Martín Socas 1999; Garcia Borja et al. 2011; García Puchol and Aura Tortosa 2006); Murcia (Martínez Andreu 2002; Martínez Andreu and Sánchez Gómez 2006); Andalusia (Aura Tortosa et al. 2009; García Borja et al. 2010; Ramos Muñoz and Lazarich González 2002); Portugal (Carvalho 2008, 2010); the Tangier peninsula (Ballouche et al. 2012; Daugas et al. 2008; Idrissi 2001); and the Eastern Rif (Linstädter 2011; Rojo Guerra 2010). Other studies focused on particular aspects, such as climate and environmental impact (Carrión et al. 2010; López Sáez et al. 2010) and the development of pottery (Bernabeu Aubán et al. 2009; 
Binder et al. 2010). Still others summarized existing data and developed integrative models (Cortés Sánchez et al. 2012; Linstädter et al. 2012; Manen et al. 2007; Zilhão 2001).

A common feature of these contributions is that they focus on the human agents of the Neolithization process. In the case of the Western Mediterranean, studies are dedicated to local Epipaleolithic foragers and Neolithic immigrants, whose origin-along with most Neolithic innovations such as pottery and domesticated specieswas in the Eastern Mediterranean. Recent genetic studies attest to an advance of Neolithic settlers from the eastern Mediterranean into the area of Valencia (Pinhasi et al. 2012). From here, the knowledge of pottery making, animal husbandry, and cultivation seems to have infiltrated the Alboran Territory. The continued existence of local hunter-gatherers in Portugal and northern Africa, as well as the very local character of the Early Neolithic, suggests that the transfer and modification of Neolithic innovations followed the existing networks along the coastal channels. By contrast, forager groups in the hinterland adopted these innovations in a step-bystep manner. In many cases, foraging strategies continued to be pursued with food production becoming part of a multifaceted economy. This was a development that was first observed in more arid environments (Morales et al. 2013). The transitional process seemed to have been short-lived so that domesticated species reached Andalusia and Portugal already by $7.5 \mathrm{ka}$ cal BP (Aura Tortosa et al. 2009; Carvalho 2010) and the eastern Rif as early as $7.6 \mathrm{ka}$ cal BP (Linstädter and Kehl 2012).

The earliest evidence of Neolithic innovation in Morocco came from the Mediterranean littoral. One of the centers of this transitional process was the eastern Rif. The Epipaleolithic started about 11,500 cal BP at the beginning of the Holocene. Rising temperatures and precipitation (Cacho et al. 2001; Combourieu Nebout et al. 2009; deMenocal et al. 2000; Kuhlmann et al. 2004) resulted in afforestation and different land-use strategies of the local hunter-gatherer communities (Linstädter 2008). The lithic inventories of the Epipaleolithic show clear affinities to the preceding Iberomaurusian. Both have a bladelet industry and domination of the tool kit by backed bladelets. The end of the Epipaleolithic is hard to define. The Epipaleolithic people possibly never disappeared, but with the emergence of the Neolithic, their lifestyle and lithic technology slowly changed. The upper part of the Hassi Ouenzga Abri stratigraphy, dated to $5.790 \pm 78$ cal BP (UTC
6184), showed a lithic inventory in a clearly Epipaleolithic tradition (Linstädter 2004, p. 70). The lithic material was associated with domesticated animals and a typical Late Neolithic pottery, mainly decorated by comb impressions not made in a rocker stamp technique, which is statistically different from Early Neolithic ceramics (Linstädter 2004, p. 100). This record might be an indication that Epipaleolithic traditions continued far into the sixth millennium cal BP.

Thanks to the recent excavation of Ifri Oudadane, the onset of the Neolithic is slightly better defined. The Neolithic transition occurred at about $7.6 \mathrm{ka}$ cal BP and was very well documented in the stratigraphy by the first appearance of pottery and domesticated species such as cereals, legumes, and ovicaprids (Morales et al. 2013). Large notched blades indicate changes in lithic tool production. The rich pottery assemblage, together with the aforementioned radiocarbon data, allow a subdivision of the Early Neolithic into three sub-phases (ENA to ENC). The earliest dated pottery from the hinterland came from the site of Hassi Ouenzga Abri (7.575 \pm 45 cal BP, KIA 434). The inventory was classified as Epipaleolithic with pottery because no evidence of food production could be found. If we assume that the site was occupied since the Epipaleolithic, one may ask whether the temporal resolution of a dynamic cave site is high enough to provide a correct date. How the Neolithic innovations dispersed throughout the area is hard to say at the moment. The sites of Mtlili 5 and 6, as well as Taoungat 7 and Hassi Ouenzga Abri (lower layer, 7,600-5,800 cal BP), did not contain any domesticated species. The first appearance of domesticated animals in an interior site is dated to $5.790 \pm 78 \mathrm{cal} \mathrm{BP}$ (UTC 6184) from the upper layer of Hassi Ouenzga. So far, the current evidence shows a 1,600-year gap between the first appearance of Neolithic innovations on the coast and their arrival in the interior (Linstädter et al. 2018).

It can be said that climate, as well as environmental changes, had a notable impact on the course of the Moroccan Neolithic transition. While the neolithization itself seems to have been triggered by socioeconomic factors, the end of the Early Neolithic ca. $6.3 \mathrm{ka} \mathrm{cal} \mathrm{BP,}$ the enforced Saharan impact during the Late Neolithic from $6.0 \mathrm{ka}$ cal BP onwards, and the end of the Neolithic as a whole at about $4.2 \mathrm{ka}$ cal BP correspond closely to climate and environmental changes (Linstädter 2016). The occurrence of Neolithic innovations in the Western Mediterranean can be traced back to the advance of 
Neolithic groups at least up to the area of Valencia (Pinhasi et al. 2012, fig. 1a). From there, these innovations entered the western Mediterranean, where they were distributed via the already existing Epipaleolithic networks. Single components such as pottery and domesticated species were adopted step by step, individually integrated and developed further. The latter is attested by the invention of very different pottery forms and decoration on the African side. The fast adoption of pottery technology in Morocco could have been favored by the semi-sedentary way of life of the local foragers. The keeping of livestock and the cultivation of crops and legumes did not become the dominant mode of subsistence during the Moroccan Early Neolithic. Instead, these agricultural economies were supplementary to the existing hunter-gatherer economy. Such a diversified subsistence strategy may have provided the perfect mechanism to cope with the uncertainties of a semiarid environment.

Exploitation of Marine Resources in the Mediterranean during Early and Middle Holocene

There is ample evidence of the exploitation of marine resources in the Mediterranean during the Epipaleolithic and Early Neolithic periods. For the eastern Mediterranean area, the Prepottery Neolithic B (PPNB) site of Shillourokambos in Cyprus, which was excavated between 1992 and 2001, is a remarkable example (Guilaine et al. 2000). The site dates between the late eleventh and early ninth millennium cal BP, the same time as the Epipaleolithic in Ifri Oudadane. The distance between the two sites is considerable, and despite evidence of seafaring in the Mediterranean during the Epipaleolithic period, the connection between these regions can only be speculated. Shillourokambos yielded a rich terrestrial fauna which originated from the Levantine mainland, but only a small amount of remains indicates the exploitation of marine resources. This included 274 remains of invertebrates. Serrand et al. (2005) identified 33 species, a number comparable with the present study, and also with considerable similarities. The authors assigned only $4 \%$ of the individuals to species that they assumed were part of the diet. These included (as in the present study) Phorcus turbinatus and a Patella species. The shells of all other species were collected after death, indicated by postmortem weathering, which is typical for an aquatic environment. The shells were typically used as jewelry - sewn-on pearls or pendants. The holes could have been natural or anthropogenic. For the latter, beating, grinding, and sawing techniques were used (Serrand et al. 2005, p. 127). Other shells were used as tools. Chipping and fragmentation indicate striking movements. Some cockles showed signs of wear on the edges, which are difficult to interpret. Last but not least, there were pieces in front of which traces of red pigments could be seen, indicating that they were either used as a kind of vessel or palette.

Moving into the western Mediterranean area, at the Iberian Peninsula, numerous Early and Middle Holocene sites with inventories of marine mollusks have been described, such as Coves de Santa Maira, Abric de la Falguera, and the Cueva del Lagrimal. Alicia Luján Navas (2016) has provided a comprehensive compilation of sites in this region from the Neolithic onward. Another case study is from Benamer (Muro d'Alcoi, Alicante) in southern Spain. The Epipaleolithic and Neolithic site dates between 8.8 and $5.8 \mathrm{ka} \mathrm{cal} \mathrm{BP.}$ Although not placed directly on the coast, the site shows a rich spectrum of marine mollusks in addition to numerous terrestrial mollusks. Besides their use as food, the shells were used for the production of tools and jewelry (Barciela González 2011, p. 240). The main use of marine mollusks was in the Mesolithic (84 pieces, $56.8 \%$ ), then in the Early Neolithic (31 pieces, 20.9\%), followed by the so-called Neolitico postcardial IC-IIA (26 pieces, 17.6\%) and the Neolitico postcardial IC (7 pieces, $4.7 \%$ ). Numbers and shares decreased over time. The number of terrestrial mollusks increased in the opposite direction (Barciela González 2011, p. 255). All pieces were manuports, and it is assumed that they had been used for the production of jewelry and tools. The most common species were Cerastoderma, Glycymeris, Columbella rustica, Nassarius corniculum, and Pecten sp. Most of these species were also found in Ifri Oudadane and were used for the same purpose. As in Shillourokambos (Cyprus), the shells showed postmortem weathering by marine organisms and partial signs of sea erosion, so it is likely that they were picked up from the beach. Some specimens were also used as sewn-on pearls or pendants. The holes also either natural or anthropogenic. Several specimens of Columbella rustica, as in Ifri Oudadane, showed perforations partly related to abrasion (Barciela González 2011, fig. XVII.7). There is an unusually large perforation on the outside of a Cerastoderma created by abrasion (Barciela González 2011, fig. XVII.6). 
Another important site on the Iberian Peninsula, located directly opposite the eastern Rif, is Cueva de Nerja (Aura et al. 2002; Jorda Pardo 1982). Nerja was inhabited from the late Upper Paleolithic (Magdalenian) to the Chalcolithic. In the use of marine mollusks, a sharp break between the Paleolithic and the Epipaleolithic could be observed. While only Cyclope neritea was used in the Magdalenian, mainly Columbella rustica and Conus mediterraneus were used in the Epipaleolithic and Neolithic. With regard to the availability of these species, the water temperature, which increased from the Late Pleistocene to the Early Holocene, was certainly of importance. From the Epipaleolithic to the Neolithic, there was a clear continuity in the use of the species. Here, as in Ifri Oudadane, Columbella rustica occurred both in the Epipaleolithic and in the Neolithic. While perforated specimens were rather rare in the Epipaleolithic, they frequently occurred in the Neolithic. Jorda Pardo (1982, p. 94) distinguished between longitudinally and laterally perforated specimens. In the case of longitudinal perforations, this was due to abrasion; lateral perforations were achieved by pushing a device through the shell (elemento punzante). The second frequently used species was Conus mediterraneus (Jorda Pardo 1982). This species also occurred both in the Epipaleolithic and Neolithic. However, it was only perforated longitudinally by abrading the spire.

For the North African coast, Haua Fteah (Prendergast et al. 2016), SMH-1, Hergla in Tunisia (Mulazzani et al. 2016), and El Zafrin off the east Moroccan Mediterranean coast (Rojo Guerra et al. 2010) should be mentioned here. El Zafrin, on the Chafarinas Islands, was studied by Rojo Guerra et al. (2010). This open-air site is located on an island in front of the Moulouya delta, which was still connected to the mainland during the Middle Holocene. The settlement was occupied in the second half of the seventh millennium cal BP (6.4$6.0 \mathrm{ka}$ cal BP). Therefore, the El Zafrín occupation coincides with the ENC of Ifri Oudadane. Pottery decoration in El Zafrín is characterized by impressions of non-denticulated shells (Rojo Guerra et al. 2010, fig. 92) supplemented by a few Glycymeris and Cardium impressions (Rojo Guerra et al. 2010, figs. 88 and 94) occasionally arranged as herringbone. Patella species and bivalves dominated the shell assemblage (Rojo Guerra et al. 2010, p. 194). Two specimens of Conus mediterraneus showed an abraded spire, as in other sites described so far; and, according to the authors, they were used as jewelry (Álvarez-Fernández 2010a, 2010b, fig. 14). Another Moroccan site of Neolithic origin, from which a considerable assemblage of marine mollusks with modifications was identified, is the cave el Mnasra in the Temara region on the Atlantic coast (El Hajraoui et al. 2012). Of the 250 documented mollusks, 234 belonged to the genus Nassarius. A total of $28 \%$ of the specimens were intentionally perforated one to three times (El Hajraoui et al. 2012, fig. 137). Detailed analysis is not yet available.

\section{Materials and Methods}

The sediment from the excavation of Ifri Oudadane was washed in a flotation system. The residue was dried and subsequently sorted in the field into lithic, pottery, bones, and shells. The analysis of the marine and terrestrial fauna was performed at the Zoologisches Forschungsmuseum Alexander Koenig (ZFMK) in Bonn. All samples of the 2011 campaign were sorted, identified, and counted as minimal number of individuals (MNI) based on unique parts such as apex (most gastropods), columella (Stromatolina), or aperture (Phorcus). For mussels (Perna), left and right valves were counted and the MNI recorded. For barnacles, crabs, and sea urchins, the occurrence of at least one fragment of each species was counted as one. The identification of bivalves and gastropods was aided by a reference collection and the illustrated guides of Huber (2010), Poppe and Goto (1991, 1993), Gianuzzi-Savelli et al. (1994), Pasteur-Humbert (1962), and others. The identification of a few rare taxa was also checked by R. Janssen (SMF). For all species, the taxonomy of the WoRMS checklist (www.marinespecies.org) was applied. Technical names and standard measurements follow Reitz and Wing (2008). Shells of Phorcus turbinatus from Mediterranean Epipaleolithic (EPI) and two Early Neolithic strata (ENA, ENB) were tested for size differences. The maximum width of the shells was measured to the nearest $0.1 \mathrm{~mm}$ using a dial caliper. Shell fragments that are not amenable to the measurement of the maximum width were not included in the data set. Since only the Epipaleolithic sample was normally distributed (Shapiro-Wilk $p=0.1$ ), a KruskalWallis test (using PAST 4.02) was used to test for significant differences in shell size between strata. 


\section{Results}

Species Diversity and Abundance

The quantitative analysis of the marine invertebrate fauna from 4,415 liters of sediment of the 2011 campaign yielded at least 40 species of shellfish: 12 bivalves, 23 gastropods, 2 barnacles, and 1 each of tusk shell, crab, and sea urchin (Table 1; Fig. 2). Eighteen to 27 species of mollusks were found in the three lower levels Epipaleolithic, Early Neolithic A, and Early Neolithic B. The poorly represented uppermost level, Early Neolithic C, contained only eight specimens of marine shells and is, therefore, not considered further. Limpets (Patella spp., Cymbula; Patellidae), topshells (Phorcus turbinatus; Trochidae), mussels (Perna perna; Mytilidae), and rock shells (Stromatolina haemastoma; Muricidae) formed $98 \%$ of the total mollusk fauna; all other taxa were below $1 \%$ and often represented by only one or two specimens (Table 1). Limpets were most common in the Epipaleolithic, while topshells dominated in the Neolithic levels (Fig. 3).

\section{Consumption and Processing of Shellfish}

We assume that an abundance of shells in the archaeological levels is a sign of human exploitation of these marine animals, accounted for mainly by limpets, topshells, Mediterranean mussels, and rockshells (Fig. 3). We also looked for the traces that collecting and processing these shells might have left. Mussels barely show signs of anthropogenic damage. However, a large portion of the shells was broken, which may have been due to the fragile condition of the Perna shells. Also, a large shell of Spondylus gaederopus was burnt, and only the massive umbo had been preserved (Fig. 2), which suggests the roasting and consumption of this species. All shells of Stromatolina were smashed to pieces. Sometimes shells were cut into half, but in most cases, they were separated into apex, columella, and whorl fragments.

Most of the extremely solid top shells (Phorcus turbinatus) were damaged or even smashed into pieces. This surprising observation caused us to look closer at the patterns of damage in a subset $(1,821$ shells) of all samples. We distinguished three categories: 1 , intact shells; 2, topped shells; and 3, smashed shells (Fig. 4). In the topped shells, the first two whorls were chopped off in a quite regular way, with some variation from one to three whorls. Up to $60 \%$ of all topshells fall in the topped category. The percentage of topped shells was low (13\%) in the Epipaleolithic levels but high (5359\%) in the Neolithic ones (Fig. 5). By contrast, the number of smashed shells was high $(71 \%)$ in the Epipaleolithic but low (26-33\%) in the Neolithic levels. This technique of topping the Phorcus shells was also documented from the Neolithic deposits of Platja del Carrabassí, Alicante (Luján Navas et al. 2014, p. 101).

Barnacles were present in low numbers at all levels. Small Balanus sp. were sometimes attached to Perna mussels or to gastropod shells; their presence in the cave must then be regarded as accidental. However, plaques of edible gooseneck barnacles (Pollicipes pollicipes) were also present, as shown by the calcified tergum, scutum, and carina (Darwin 1851; Álvarez-Fernández 2010b). Crabs were identified by their pincers and present in low numbers in all levels (Table 1); they certainly were used as food. Spines and fragments of the exoskeleton of sea urchins were regularly found, with lower numbers in the Epipaleolithic and higher numbers in the Neolithic levels (Table 1).

Size Variation of Phorcus Shells

Shell size (expressed by the maximum width) of Phorcus turbinatus shells ranged from 12.2 to $29.3 \mathrm{~mm}$ (Table 2). Median shell size decreased from $20.7 \mathrm{~mm}$ in the Epipaleolithic period (EPI) to $20.6 \mathrm{~mm}$ in ENA and, finally, $20.2 \mathrm{~mm}$ in ENB. While the decrease in median shell size between EPI and ENA was not statistically significant ( $p=0.121$ ), median shell size in ENB was significantly smaller than both in EPI $(p=0.004)$ and ENA $(p=0.031)$ (Fig. 6). The same result was found when the lower quartile was removed from all data sets to exclude immature individuals (EPI/ENA $p=0.108$; EPI/ENB $p<$ $0.001 ; \mathrm{ENA} / \mathrm{ENB} p=0.001$ ).

\section{Ornament}

Five species of gastropods and one mussel (marked by an asterisk in Table 1) showed signs of manipulation, which suggest their use as ornaments. Two perforated dove shells (Columbella rustica) were found in EPI levels (Figs. 7.3 and 7.5) and one in the ENB unit (Fig. 7.4). The latter shows an unfinished perforation. Perforated Columbella rustica shells frequently appear all around the Mediterranean during Epipaleolithic and 
Table 1 Marine shellfish species from the Ifri Oudadane levels (excavation 2011) [The three species added from the 2010 campaign (in parentheses) are not included in the total; species marked by an asterisk were also used as an ornament]

\begin{tabular}{|c|c|c|c|c|}
\hline Archaeological level & Epipaleolithic & Early Neolithic A & Early Neolithic B & Total \\
\hline Number of samples & 110 & 49 & 68 & 227 \\
\hline Volume sediment, liters & 1,986 & 965 & 1,464 & 4,415 \\
\hline \multicolumn{5}{|l|}{ Clams, scallops, mussels } \\
\hline Barbatia barbata & 1 & & & 1 \\
\hline Cardita calyculata & & & 2 & 2 \\
\hline Chama gryphoides & 1 & & & 1 \\
\hline Glans trapezia & & & 1 & 2 \\
\hline Mimachlamys varia* & (1) & & & - \\
\hline Mimachlamys sp. & & & 3 & 3 \\
\hline Perna perna & 199 & 229 & 482 & 910 \\
\hline Glycymeris sp.* & 2 & & 2 & 4 \\
\hline Acanthocardia tuberculata* & & & (1) & - \\
\hline Spondylus gaederopus & 2 & 2 & & 4 \\
\hline Lima lima & & & 1 & 1 \\
\hline Limaria tuberculata & & & 1 & 1 \\
\hline Mussel indet. & 2 & & 22 & 24 \\
\hline \multicolumn{5}{|l|}{ Tusk shells } \\
\hline Antalis vulgaris & & & (1) & - \\
\hline \multicolumn{5}{|l|}{ Gastropods } \\
\hline Cymbula safiana & & 1 & 2 & 3 \\
\hline Patella caerulea & 566 & 516 & 427 & 1,509 \\
\hline Patella ferruginea & 49 & 124 & 205 & 378 \\
\hline Patella rustica & 56 & 89 & 47 & 192 \\
\hline Patella ulyssiponensis & 357 & 501 & 424 & 1,282 \\
\hline Patella sp. & 39 & 69 & 240 & 349 \\
\hline Calliostoma sp. & & & 2 & 2 \\
\hline Clanculus jussieui & & 1 & & 1 \\
\hline Gibbula sp. & 1 & 1 & 1 & 3 \\
\hline Phorcus turbinatus & 575 & 1,342 & 1,419 & 3,336 \\
\hline Melanopsis praemorsa & 1 & & & 1 \\
\hline Cerithium vulgatum & 2 & & & 2 \\
\hline Schilderia achatidea & & & 1 & 1 \\
\hline Charonia sp. & 1 & & & 1 \\
\hline Stramonita haemastoma & 63 & 105 & 182 & 350 \\
\hline Buccinum sp. & & & 4 & 4 \\
\hline Cantharus sp. & & & 2 & 2 \\
\hline Colus jeffreysianus & & 3 & & 3 \\
\hline Columbella rustica* & $6^{*}$ & 6 & 4 & 16 \\
\hline Nassarius reticulatus* & & $1^{*}$ & & 1 \\
\hline Pusia ebenus & 2 & & & 2 \\
\hline Conus ventricosus* & $2 *$ & & (1) & 2 \\
\hline Opalia crenata & & & 1 & 1 \\
\hline Siphonaria pectinata & 4 & 12 & 1 & 17 \\
\hline Gastropoda indet. & 4 & 1 & 2 & 7 \\
\hline Total Mollusca & 1,935 & 3,003 & 3,478 & 8,416 \\
\hline
\end{tabular}


Table 1 (continued)

\begin{tabular}{llcll}
\hline Archaeological level & Epipaleolithic & Early Neolithic A & Early Neolithic B \\
\hline Number of species & 22 & 17 & 25 & Total \\
Mollusks per liter & 1.0 & 3.1 & 2.4 & 1.9 \\
Barnacles, crabs, sea urchins & & & 49 & 118 \\
Balanus sp. & 38 & 31 & 20 & 47 \\
Pollicipes sp. & 12 & 15 & 9 & 29 \\
Decapoda & 13 & 7 & 65 & 139 \\
Echinoidea, Paracentrotus & 31 & 43 & 3,621 & 8,749 \\
Total shellfish & 2,029 & 3,099 & 2.5 & 2.0 \\
Shellfish per liter & 1.0 & 3.2 & & \\
\hline
\end{tabular}

Neolithic times. Because of the way they were perforated, it is assumed that they were beads sewn onto the clothing. They were documented in Shillourokambos (Serrand et al. 2005, fig. 5h) and in Benamer, in the Mesolithic (Barciela González 2011, p. 250), as well as early Neolithic times (Barciela González 2011, fig. XVII.7). During the Early Neolithic, beads with traces of ochre are known. Furthermore, Columbella rustica beads were excavated at Epipaleolithic and Neolithic layers of Cueve da Nerja (Jorda Pardo 1982, fig. 1.1). According to Serrand et al. (2005, p. 127) and Barciela González (2011), fig. XVII.7), perforation in Shillourokambos and Benamer was accomplished by direct or indirect percussion.

Shells of Conus ventricosus and Nassarius reticulatus were also interpreted as sawn-off beads. At Ifri Oudadane, perforated Conus ventricosus shells appeared in Epipaleolithic (Fig. 7.2) and ENB (Fig. 7.1) layers. Comparable examples were also found in Shillourokambos (Serrand et al. 2005, fig. 5a), Nerja (Jorda Pardo 1982, fig. 1.5), and at Zafrín, Chafarinas islands (ÁlvarezFernández 2010a, fig. 14). One Nassarius reticulatus bead is identified in the ENA unit of Ifri Oudadane (Fig. 7.6). A unique find was a small fragment of a cone shell ring (Fig. 7.7), probably made from the outer whorls of a Conus ventricosus shell. The piece came from the ENC unit, and its external diameter was $16-17 \mathrm{~mm}$, which conforms to the maximum shell diameter of a middle-sized Conus shell, such as shown in Fig. 2.

A 40-mm-long section of a tusk shell (Antalis vulgaris), from the Epipaleolithic layer, was polished at both ends and the outer surface (Fig. 7.9), and may have been used as a bead. A similar piece is documented from the PPNB layers of Shillourokambos, Cyprus (Serrand et al. 2005, fig. 5b) and therefore has the same age as the specimen from Ifri Oudadane. One fragment of a Mediterranean mussel (Perna perna?) shows a round hole (Fig. 7.8). The piece came from the ENB unit. Its fresh edges, which are not rounded or polished, suggest that the piece was an unfinished pendant. The same pattern is seen on a scallop specimen (Mimachlamys varia), also from the ENB unit. Likewise, this could be an unfinished pendant (Fig. 7.10). According to Serrand et al. (2005, p. 127), this kind of perforation could be accomplished by direct or indirect percussion.

Bittersweet clams (Glycymeris sp.) were mostly found as polished and modified pieces. Only one complete shell was found in the Early Neolithic B level (Fig. 8.1). A second, nearly complete piece came from an Epipaleolithic context (Fig. 8.3). Both pieces showed a perforated umbo and were probably worn as pendants. The perforation of an umbo can be accomplished by percussion or abrasion but could also occur naturally (Barciela González 2011, fig. XVII.4; Serrand et al. 2005, fig. 5c, d). A third Glycymeris shell piece can also be interpreted as a pendant (Fig. 8.4). It came from the

Fig. 2 Shells and shell fragments of marine species identified in the archaeological levels of Ifri Oudadane: 1 Perna perna; 2 Glycymeris sp.; 3 Spondylus gaederopus; 4 Mimachlamys varius; 5 Mimachlamys sp.; 6 Lima lima; 7 Limaria tuberculata; 8 Barbatia barbata; 9 Acanthocardia tuberculata; 10 Cardita calyculata; 11 Chama gryphoides; 12 Glans trapezia; 13 Patella caerulea; 14 P. ulyssiponensis; 15 P. ferruginea; 16 Cymbula safiana; 17 Patella rustica; 18 Calliostoma sp.; 19 Clanculus jussieui; 20 Gibbula sp.; 21 Phorcus turbinatus; 22 Cerithium vulgatum; 23 Melanopsis praemorsa; 24 Schilderia achatidea; 25 Charonia sp.; 26 Stromatolina haemastoma; 27 Buccinum sp.; 28 Cantharus sp.; 29 Colus jeffreysianus; 30 Columbella rustica; 31 Nassarius reticulatus; 32 Pusia ebenus; 33 Conus ventricosus; 34 Opalia crenata; 35 Siphonaria pectinata 

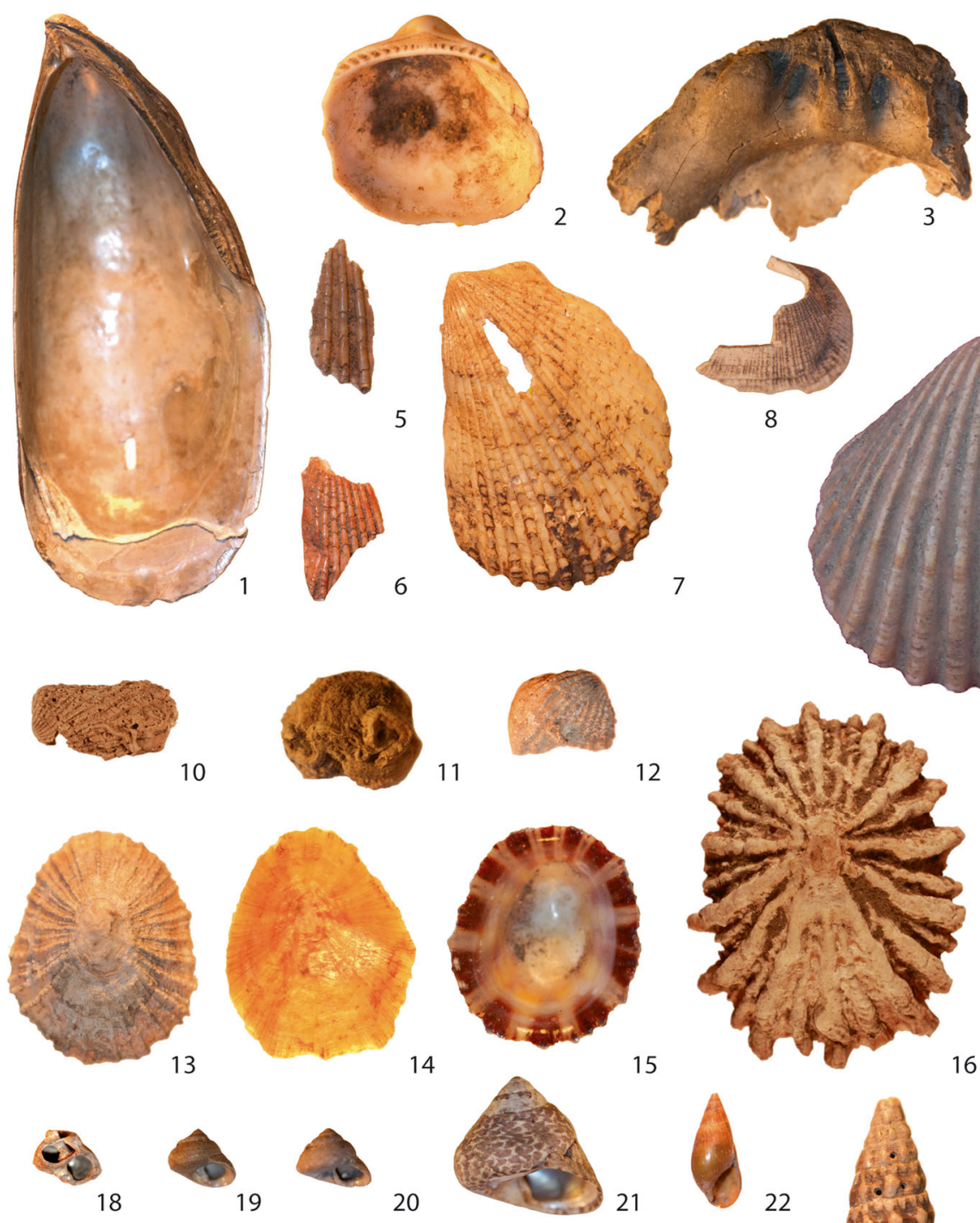

20
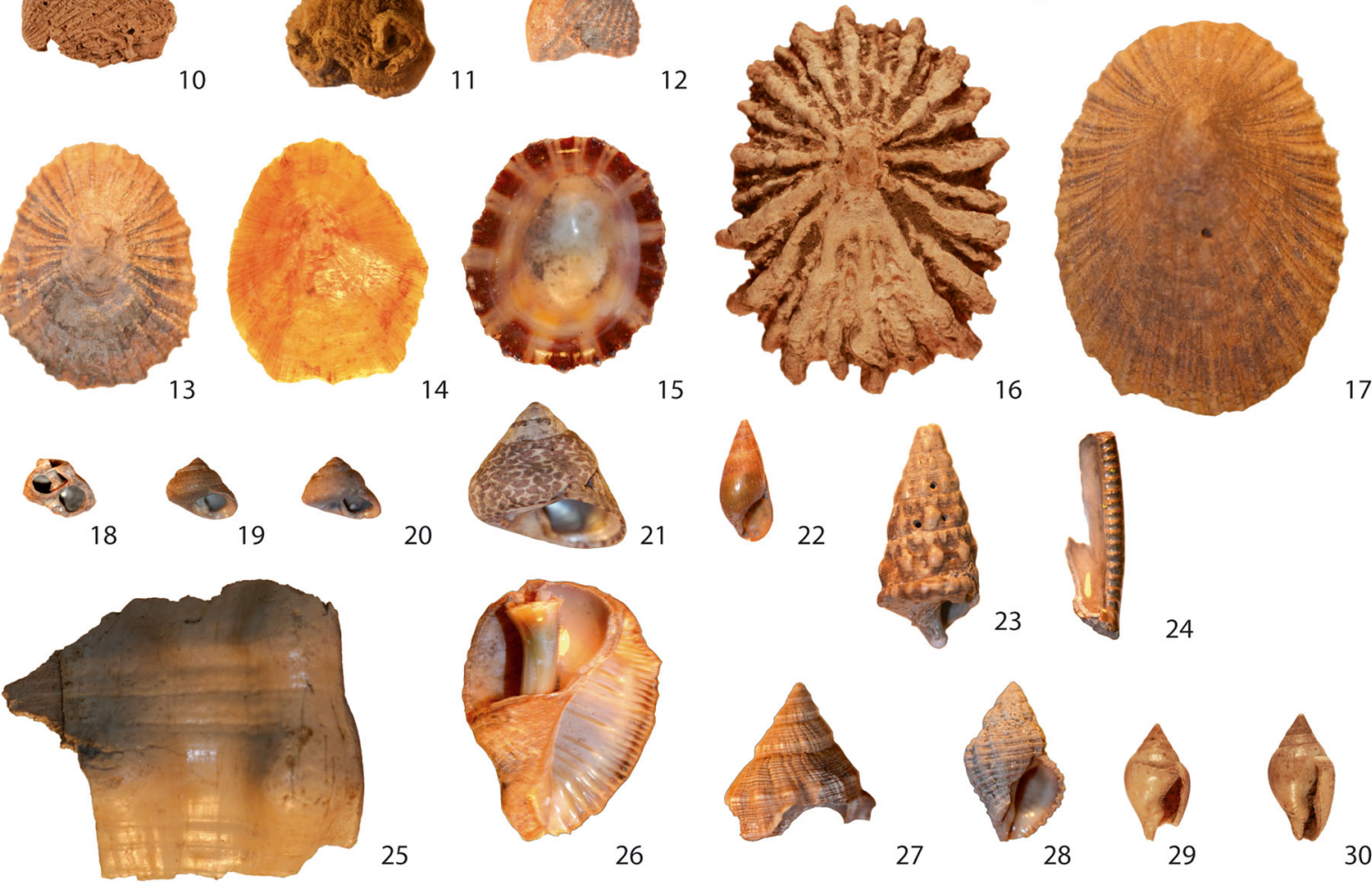

24
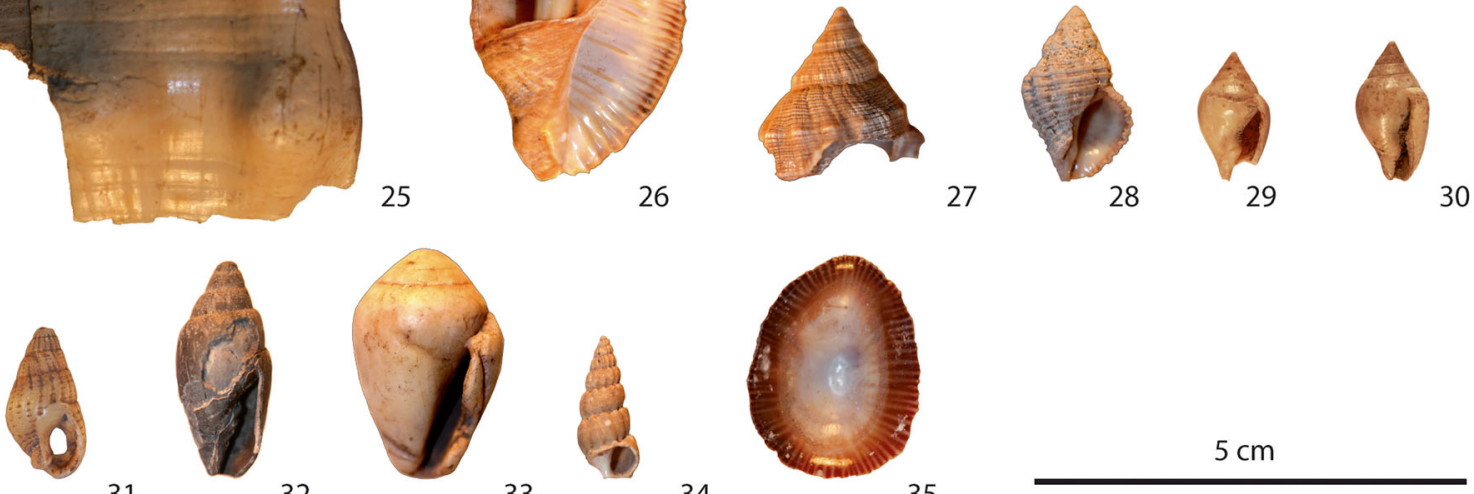

31

32

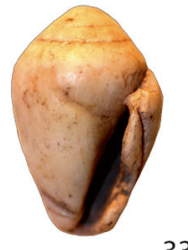

33

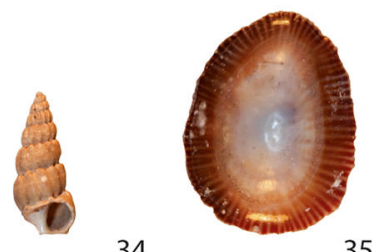

$5 \mathrm{~cm}$ 
Fig. 3 Distribution of the main components in the Epipaleolithic (EPI), Early Neolithic A (ENA), and Early Neolithic B (ENB) levels

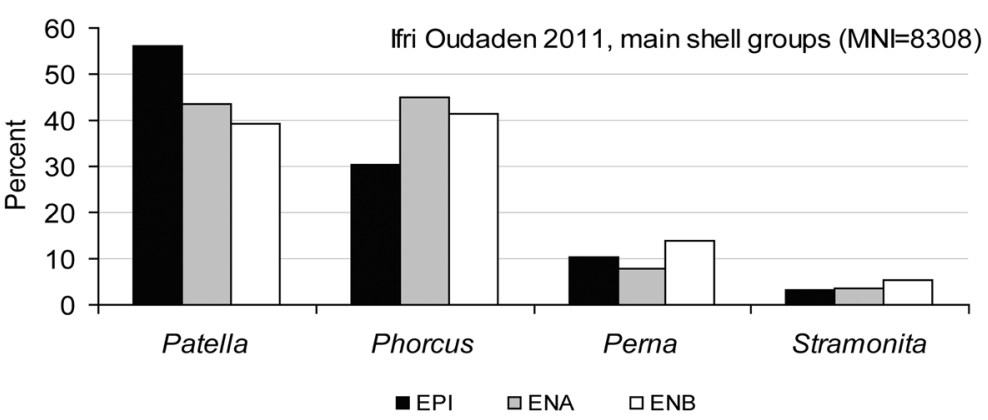

ENA unit. Its perforation is biconical, which indicates drilling from both sides. In contrast to the previously mentioned specimens, only a fragment of the whole shell was used. The edges show strong evidence for the prolonged use of the piece.

Tools

A few pieces of the shells were used as tools. Prominent among these are the so-called "polishers," assumed to have been used in the manufacture of ceramic vessels. They are extremely over-shaped and show clear traces of use so that a determination of the species is only possible to a limited extent. However, we assume that the pieces shown here were made of Glycymeris sp. They appear in both ENA (Fig. 8.7) and ENB (Figs. 8.2, 8.4) layers. However, such pieces also appear in an Epipaleolithic context (Fig. 8.8). Since no pottery was produced in the latter, there must have been other uses for these "polishers," which is why the term should be used with caution. This need for caution is reinforced by the fact that comparable pieces are also documented from the Prepottery Neolithic B (PPNB) of Shillorokambos. In this site, specimens were made on the base of cockles (Cardiidae, Acanthocardia, and Cerastoderma sp.) and showed use-wear edges

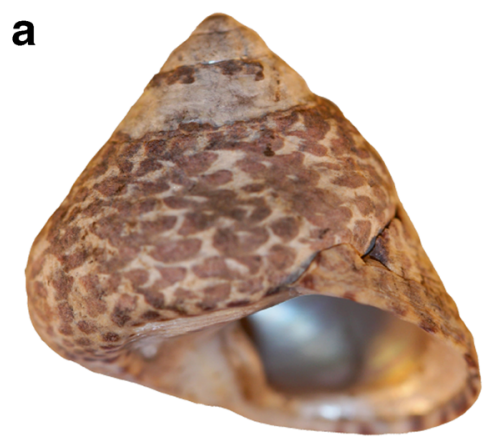

b
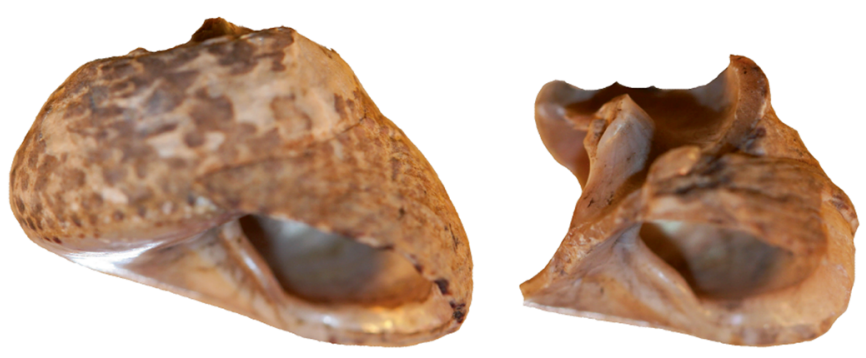

d

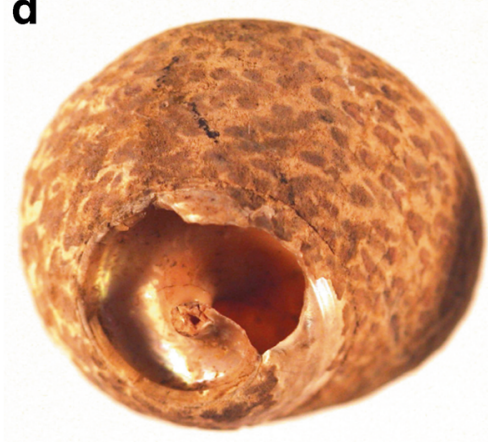

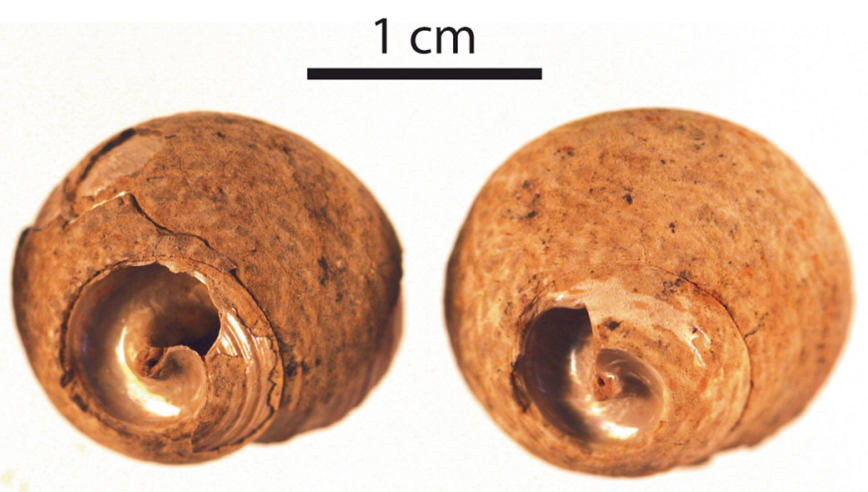

Fig. 4 Intact and manipulated shells of Phorcus turbinatus; a intact, b topped, $\mathbf{c}$ smashed 
Fig. 5 Percentage of intact and damaged shells of Phorcus turbinatus $(\mathrm{MNI}=1,821)$ in the three main cultural periods

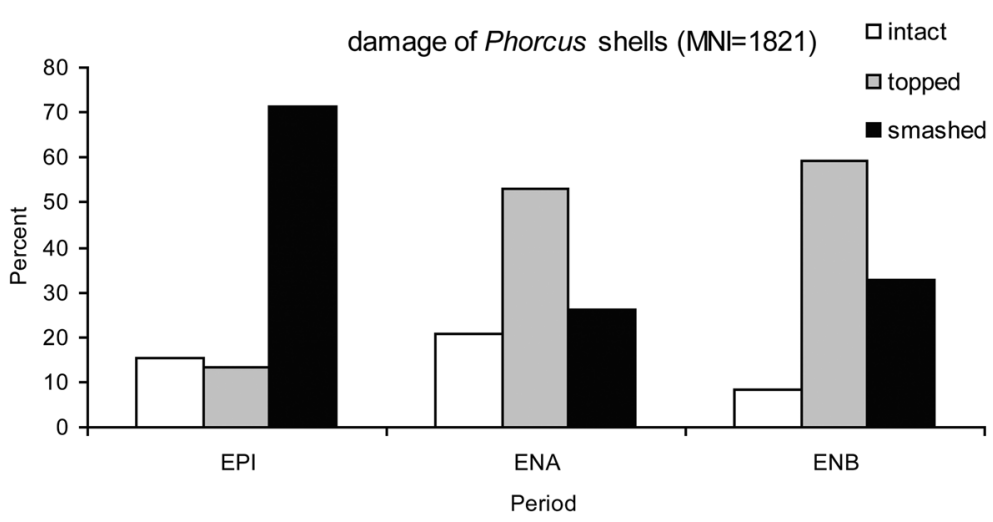

(Serrand et al. 2005, p. 127). The last piece to mention here is a so-called "Palette," probably made on a Glycymeris sp. shell (Fig. 8.5). The artifact came from ENB context and is extremely hewn, and it also shows visible traces of ochre. Comparable pieces were also documented at Shillorokambos, where they were used as pallets or containers (Serrand et al. 2005, p. 127 and fig. 7b).

\section{Discussion}

Marine mollusks play a major role in the everyday lives of the inhabitants of Ifri Oudadane, both for food and as raw material for jewelry and tools. Their role in the diet resulted from the location of the site by the sea. These marine mollusks provided essential nutrients that cannot be compensated by terrestrial resources in the region. In addition to proteins, they are important sources of iron, calcium, and phosphorus, as well as vitamins such as $\mathrm{A}, \mathrm{B}_{12}$, and $\mathrm{C}$. The shells were also favored raw materials for tools and jewelry because of their variety of shapes, hardness, and good workability.

It is striking that the species used for the respective purposes - food, tool, and jewelry — are mutually exclusive. Shells of the species used for consumption such as

Table 2 Mean, median, and range of the width of Phorcus turbinatus shells from the three cultural levels

\begin{tabular}{lllll}
\hline Archaeological level & $n$ & $\bar{x} \pm \sigma$ & $\widetilde{x}$ & Range \\
\hline Early Neolithic B & 818 & $20.3 \pm 2.3$ & 20.2 & $15.9-29.3$ \\
Early Neolithic A & 817 & $20.6 \pm 2.3$ & 20.6 & $12.2-28.1$ \\
Epipaleolithic & 161 & $20.9 \pm 2.2$ & 20.7 & $14.6-27.8$ \\
\hline
\end{tabular}

limpets, topshells, mussels, and rockshells were not used as jewelry or tools. These intertidal species were collected near the beach during the low tide. Species such as Columbella rustica, Conus ventricosus, and Nassarius reticulatus were used for jewelry or tools, and were not consumed. These live predominantly in the open sea and abrasion as well as parasite damage show that the shells of the already dead animals were collected on the beach. Figure 9 shows the process of collecting the mollusks, transporting them to the shelter, processing them into jewelry and tools, or for consumption and, finally, discarding the shells inside the shelter.

The Mediterranean Sea is a biodiversity hotspot (Coll et al. 2010). The abundance of shellfish is particularly high in the westernmost part of the Mediterranean Sea, where our study site is located. However, many of the taxa listed in Table 1 are also currently known from Tunisia (Zamouri-Langar et al. 2011). Coll et al. (2010) listed 2,113 species of Mollusca, 2,239 species of Crustacea, and 154 species of Echinodermata, among others, as occurring in the Mediterranean Sea. The people who inhabited Ifri Oudadane, especially in the early to midHolocene, made use of this food resource. They collected a minimum of 40 species of shellfish ( 36 mollusks, plus barnacles, crabs, and sea urchins). This is three times the number recorded from the Grotte des Contrebandiers (Steele and Álvarez-Fernández 2011) on the Atlantic coast of Morocco.

The excavated deposits of Ifri Oudadane yielded 22 species of mollusks in the Epipaleolithic, 17 in the Early Neolithic A, and 25 in the Early Neolithic B. The overall density (shellfish per liter of sediment) was higher in both of the Neolithic levels (Table 1). In terms of their abundance, only four mollusks were of economic importance: limpets, topshells, mussels, and rockshells (Fig. 3). With $42.3 \%$, the percentage of topshells 
Fig. 6 Size distribution of Phorcus shells in the three cultural levels

\section{ENB $(n=818)$}

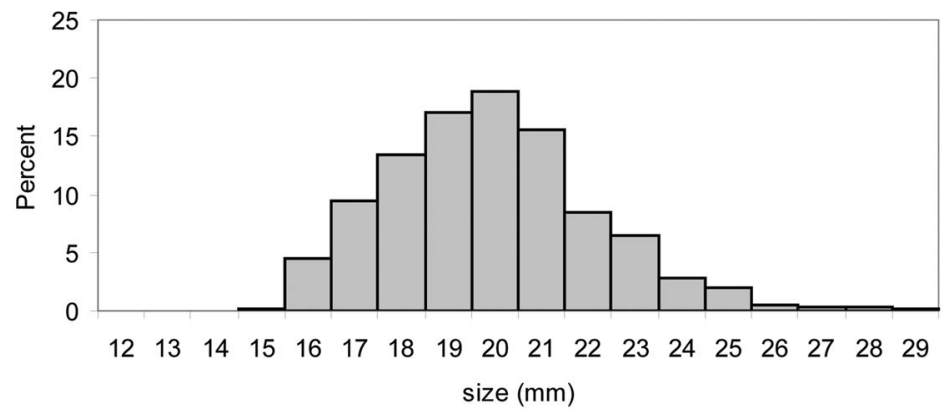

ENA $(n=817)$

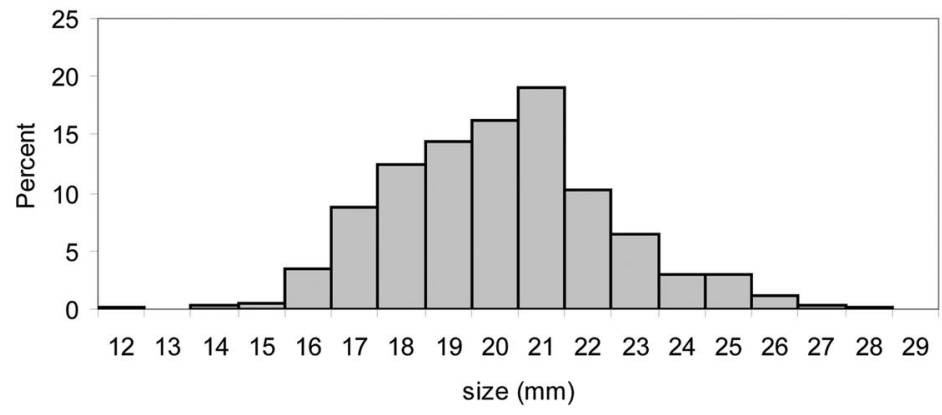

$\operatorname{EPI}(n=161)$

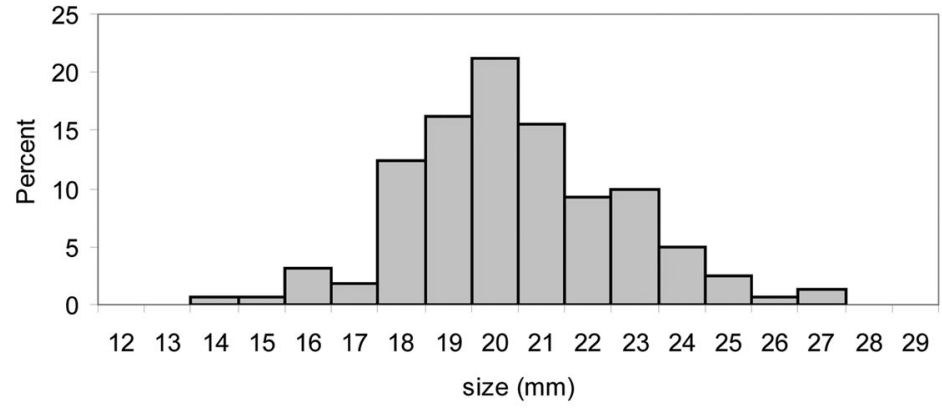

(Phorcus) was higher than in any other site along the Moroccan coast (Table 3). The nearby site Ifri Armas yielded a similar value (38.9\%), based on Lorenz (2011) and our own re-examination of the original material. In contrast, the nearby site Zafrín (Chafarinas Islands) yielded only 4.8\% (Álvarez-Fernández 2010a).

Barnacles are not frequently found in coastal archaeological sites. This may be due to the small size of their remnants and partly due to identification problems. While the barnacle, Balanus sp., is often found complete and easily recognized, the edible Pollicipes is always found as disarticulated plaques, which can easily be mistaken as a tiny bivalve. Álvarez-Fernández (2010b) has shown how to identify the various components of Pollicipes, based on the Neolithic specimens from the Chafarinas Islands. Surprisingly, Pollicipes plaques were dominant (40\% MNI), followed by Patella sp. (36\%) and Mytilus sp. (16\%), in the faunal remains of Rocha das Gaviotas, an Early Neolithic site in Southern Portugal (Dean and Carvalho 2011). 

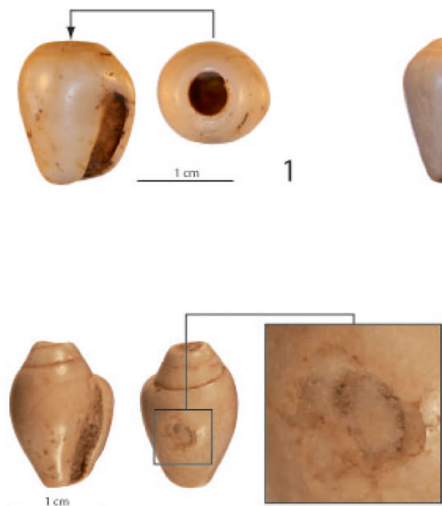

4
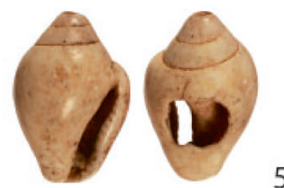

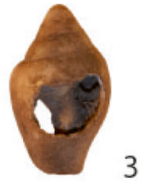

3

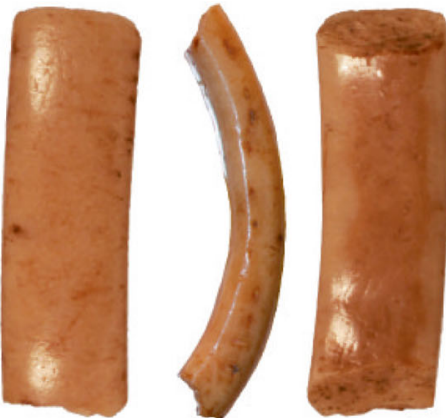

6
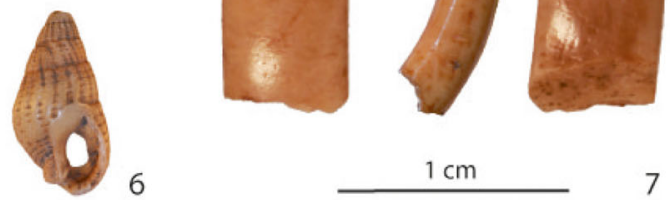
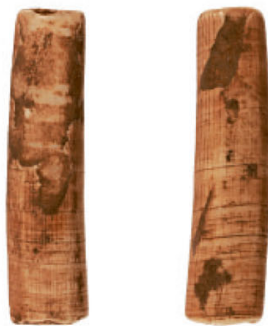

9

8

\section{$5 \mathrm{~cm}$}

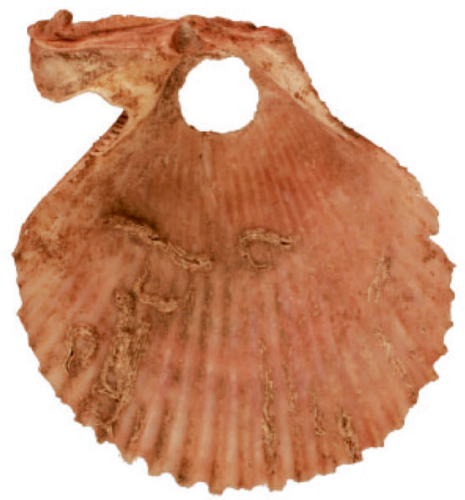

Fig. 7 Shells modified for use as ornament. 1,2: perforated Conus ventricosus shells; 3-5: perforated Columbella rustica; 6: perforated Nassarius reticulatus shell; 7: fragment of a cone shell ring;

A decrease in average shell size (but not significant) from Epipaleolithic to Early Neolithic strata was shown for Phorcus turbinatus (Table 2). This fact could possibly be explained by different scenarios. Steele and Klein
8: perforated fragment of a Perna sp.; 9: long section of an Antalis vulgaris; 10: perforated Mimachlamys varia

(2008) showed a similar trend for various South African gastropod species from the Middle Stone Age to the Later Stone Age, which was probably caused by an increasing human population density and higher 

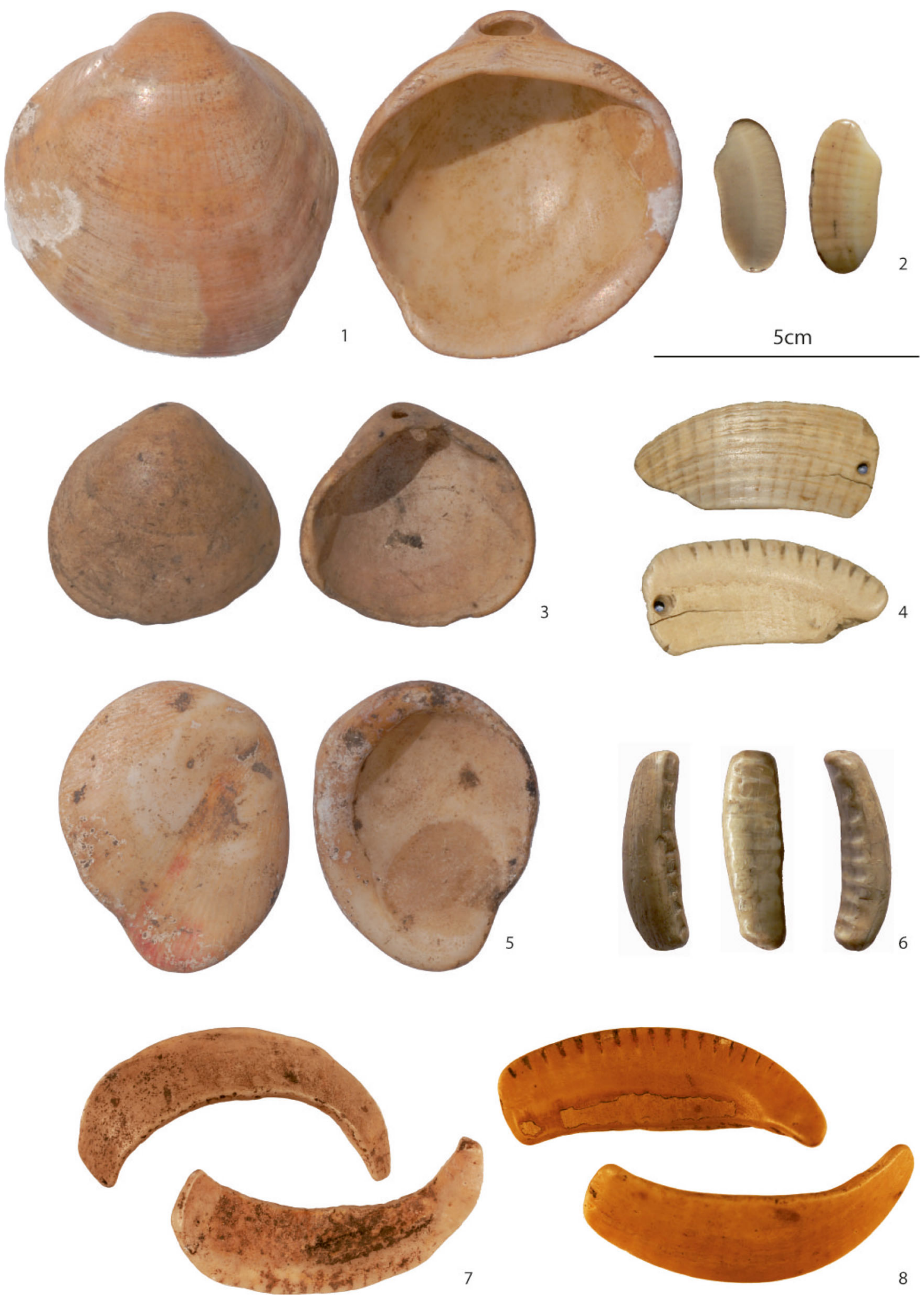
Fig. 8 Shells modified for use as ornament and tools. 1: complete perforated Glycymeris sp. shell; 2: extremely overshaped shell fragment that shows clear traces of use, unclear species; 3 : nearly complete Glycymeris sp. shell; 4: perforated fragment of a Glycymeris sp. shell; 5: extremely overshaped shell fragment (probably Glycymeris sp.) providing visible traces of ochre; 6-8: extremely overshaped shell fragments that show traces of use

exploitation of marine resources. Espinosa et al. (2009) reported the same correlation of shell size and human exploitation for limpets in modern protected and unprotected eastern Mediterranean areas. Since larger gastropods are more visible and more economical to collect, selective harvesting of larger individuals by Neolithic gatherers should be expected. In the case of Phorcus turbinatus, this could have resulted in an evolutionary pressure to divert resources from growth to reproduction at an earlier age. However, other environmental factors, such as mean temperature, could have also influenced adult shell size. Climate change may thus also explain trends in size (Teske et al. 2007).

The rate of manipulation of the Phorcus shells (Table 4) increased strongly from the Epipaleolithic to the Early Neolithic B. The same happened, but even more pronounced, with the perforation of terrestrial shells, mainly of genus Otala (Hutterer et al. 2014).
While the Phorcus, with their thick shells, were smashed or decapitated (Fig. 4), the Otala shells were perforated with small stone tools (Hutterer et al. 2011, 2014). McBurney $(1967,306)$ studied marine mollusks of the Neolithic of Haua Fteah (Cyrenaica, Libya). He found that "Throughout the succession[,] marine shells other than Patella and Trochus are extremely rare and traces of any kind of artificial modification on them rarer still." Occasionally he found Dentalium and a grooved shell of Cypraea sp. A small shell bracelet fragment reported in McBurney (1967, plate IX.11) strongly resembles the fragment of a Conus shell ring in Ifri Oudadane (Fig. 7.7). Kemp (1967) discussed the Haua Fteah fragment in the context of almost identical bracelets from Neolithic Egypt (internal diameter not exceeding $1.7 \mathrm{in}=4.3 \mathrm{~cm}$ ) and estimated the internal diameter of the Haua Fteah fragment as 5-6 cm.

The study of jewelry and tools made from shells leads to two significant results. One is the question of the continuity between the Epipaleolithic and Neolithic. It is evident that the shells of Columbella rustica, Conus ventricosus, and Nassarius reticulatus were used in both phases as sewn-on beads, which suggests a similar way of dressing, and therefore a continuity of tradition. The same can be said for the use of perforated Glycymeris

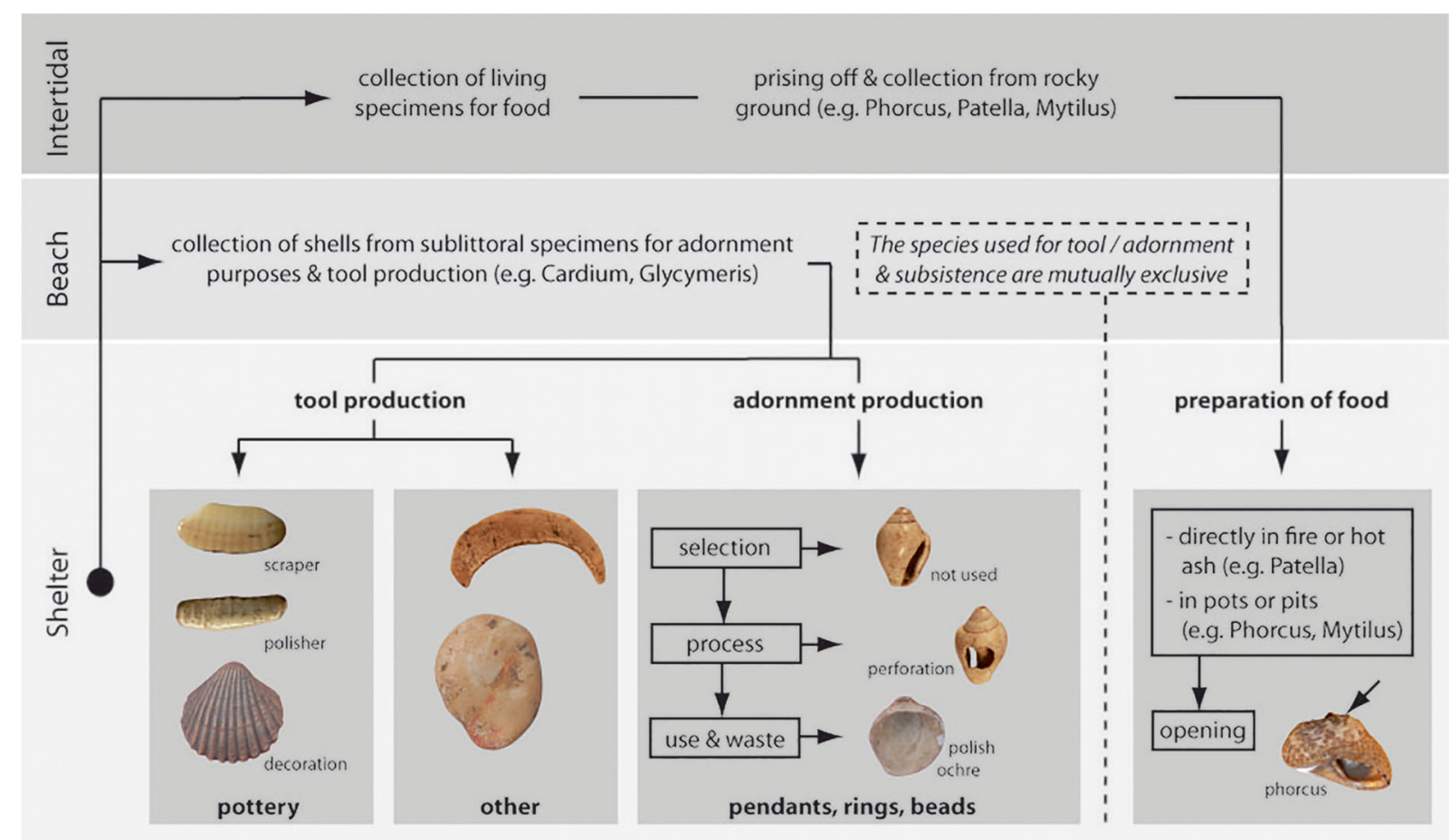

Fig. 9 Overview of all activities related to the procurement and use of marine mollusks 
Table 3 Comparison of abundance and manipulation rates of marine (IOd2011) and terrestrial (IOd2010) shells in the Ifri Oudadane trench (after Hutterer et al. 2014)

\begin{tabular}{lllclrl}
\hline $\begin{array}{l}\text { Archaeological } \\
\text { level }\end{array}$ & $\begin{array}{l}\text { MNI } \\
\text { marine }\end{array}$ & $\begin{array}{l}\text { Marine } \\
\text { shells per liter }\end{array}$ & MNI terrestrial & $\begin{array}{l}\text { Terrestrial } \\
\text { shells per liter }\end{array}$ & $\begin{array}{l}\text { Topped } \\
\text { Phorcus }\end{array}$ & $\begin{array}{l}\text { Perforated } \\
\text { helicids }\end{array}$ \\
\hline Early Neolithic B & 3,478 & 2.4 & 4,101 & 3.6 & $59.1 \%$ & $81.3 \%$ \\
Early Neolithic A & 3,003 & 3.1 & 536 & 1.5 & $53.1 \%$ & $59.1 \%$ \\
Epipaleolithic & 1,935 & 1.0 & 1,034 & 1.4 & $13.3 \%$ & $1.5 \%$ \\
\hline
\end{tabular}

bivalves as pendants. The shell tools at the site also point in this direction of cultural continuity. The so-called "polisher shells" appeared in both Epipaleolithic and Neolithic layers, although their function is not yet clear. The analysis of the stone tools from Ifri Oudadane and Ifri n'Etsedda also support settlement and cultural continuity during the transition from the Epipaleolithic to the Early Neolithic (Broich et al. 2020; Linstädter et al. 2015).

Another aspect of this study deals with the distribution of the shell artifacts. The ornamental objects, such as pendants and beads (as in the case of the Antalis vulgaris pearl), and the tools showed a distribution from northwest Africa over the Iberian Peninsula toward the Eastern Mediterranean area. In the Early to Middle Holocene, there existed a trans-Mediterranean culture that was characterized by specific clothing and accessory style as an expression of regional identity. These groups could have been responsible for the spread of the Neolithic innovations, at least in the western Mediterranean area. Altogether, the following scenario can be drawn up for the transition to food production in the region. With the arrival of Neolithic innovations such as ceramics and domesticated species in the Mediterranean Maghreb, no population replacement seems to have taken place. In addition to the continuity in the lithic technology, the use of marine mollusks also points toward population continuity between the Epipaleolithic and Early Neolithic. The existence of very similar jewelry objects across most of the Mediterranean region suggests that the Early and Middle Holocene populations of the Mediterranean Maghreb were integrated into networks through which the Neolithic innovations reached the region. These innovations were integrated slowly into the prevailing hunting-gathering subsistence models. Due to the diversity of the natural environment, the subsistence strategy could vary greatly from group to group and from one time (even season) to the other

Table 4 Comparison of the major molluscan groups from the Neolithic levels of Ifri Oudadane, Ifri Armas, Zafrín (all Mediterranean), and Grotte des Contrebandiers (Atlantic)

\begin{tabular}{|c|c|c|c|c|}
\hline Archaeological site & Ifri Oudadane & Ifri Armas & Zafrín, Chafarinas & Grotte des Contrebandiers \\
\hline Reference & This study & Lorenz 2011 and this study & Álvarez-Fernández 2010a & $\begin{array}{c}\text { Steele and Álvarez } \\
\text { Fernández } 2012\end{array}$ \\
\hline Sea & Mediterranean & Mediterranean & Mediterranean & Atlantic \\
\hline Level & Early Neolithic A + B & Early Neolithic level IV & Early Neolithic C & Neolithic \\
\hline MNI & 6,481 & 463 & 147 & 87 \\
\hline Bivalves & $11.9 \%$ & $8.4 \%$ & $4.8 \%$ & $26.4 \%$ \\
\hline Mytilus sp. & - & - & $4.8 \%$ & $1.1 \%$ \\
\hline Perna perna & $10.9 \%$ & $7.3 \%$ & - & $23.0 \%$ \\
\hline Other and indet. & $1.0 \%$ & $1.1 \%$ & $2.0 \%$ & $2.3 \%$ \\
\hline \multicolumn{5}{|l|}{ Gastropods } \\
\hline Phorcus spp. & $42.3 \%$ & $38.9 \%$ & $6.8 \%$ & $2.3 \%$ \\
\hline Patella spp. & $40.5 \%$ & $48.6 \%$ & $81.6 \%$ & $35.6 \%$ \\
\hline Stramonita haemastoma & $4.4 \%$ & $2.6 \%$ & $2.7 \%$ & $1.1 \%$ \\
\hline Other and indet. & $0.9 \%$ & $1.5 \%$ & $2.0 \%$ & $34.5 \%$ \\
\hline
\end{tabular}


(Morales et al. 2016). However, a common feature is the high proportion of gathered food. In this semi-arid and dynamic environment, food production seems to have been a risk-minimizing facet during the Early Neolithic period $(7,600-6,300 \mathrm{cal} \mathrm{BP})$.

Acknowledgments Our fieldwork was funded by Deutsche Forschungsgemeinschaft DFG (Collaborative Research Centre 806Our Way to Europe), and supported by Deutsches Archäologisches Institut/KAAK, Bonn, Institute National des Sciences de l'Archéologie et du Patrimoine (INSAP), Rabat, and Zoologisches Forschungsmuseum Alexander Koenig (ZFMK), Bonn. Photographs of shells were made by Jan Decher/ZFMK. Assistance in the field was provided by Ines Medved, Luise Lorenz, Kim Hofmann, and Abdesalam Amarir. We also thank R. Janssen (SMF Frankfurt) for checking the identification of some marine shells, and the reviewers for their constructive comments.

Funding Open Access funding enabled and organized by Projekt DEAL.

\section{Compliance with Ethical Standards}

Conflict of Interest The authors declare that they have no conflict of interest.

Open Access This article is licensed under a Creative Commons Attribution 4.0 International License, which permits use, sharing, adaptation, distribution and reproduction in any medium or format, as long as you give appropriate credit to the original author(s) and the source, provide a link to the Creative Commons licence, and indicate if changes were made. The images or other third party material in this article are included in the article's Creative Commons licence, unless indicated otherwise in a credit line to the material. If material is not included in the article's Creative Commons licence and your intended use is not permitted by statutory regulation or exceeds the permitted use, you will need to obtain permission directly from the copyright holder. To view a copy of this licence, visit http://creativecommons.org/licenses/by/4.0/.

\section{References}

Álvarez-Fernández, E. (2010a). Arqueomalacofauna marina del yacimiento neolítico de Zafrín (Isla de Congreso, Islas Chafarinas). In M. A. Rojo Guerra, R. Garrido Pena, J. A. Bellver Garrido, A. Bravo Nieto, I. García Martínez de Lagrán, S. Gámez Gómez, \& C. Tejedor Rodríguez (Eds.), Zafrín un asentiamiento del Neolítico antiguo en las Islas Chafarinas, Norte de àfrica, Espana (pp. 193-212). Valladolid: Universidad de Valladolid, Secretariado de Publicaciones e Intercambio Editorial.

Álvarez-Fernández, E. (2010b). Percebes y bellotas de mar: Los cirrípedos del yacimiento neolítico de El Zafrín (isla de
Congreso, islas Chafarinas). In M. A. Rojo Guerra, R. Garrido Pena, J. A. Bellver Garrido, A. Bravo Nieto, I. García Martínez de Lagrán, S. Gámez Gómez, \& C. Tejedor Rodríguez (Eds.), Zafrín un asentiamiento del Neolitico antiguo en las Islas Chafarinas, Norte de àfrica, Espana (pp. 213-222). Valladolid: Universidad de Valladolid, Secretariado de Publicaciones e Intercambio Editorial.

Angelucci, D. E., Boschian, G., Fontanals, M., Pedrotti, A., \& Vergès, J. M. (2009). Shepherds and karst: The use of caves and rock-shelters in the Mediterranean region during the Neolithic. World Archaeology, 41, 191-214.

Aura Tortosa, J. E., Jordá Pardo, J. F., Pérez Ripoll, M., Morales Pérez, J. V., García Puchol, O., Gonzáles-Tablas Sastre, B., Avezuela Aristu, J., \& B. (2009). Epipaleolítico y Mesolítico en Andalucía oriental. Primeras notas a partir de los datos de la Cueva de Nerja (Málaga, España). In M. P. U. Miranda \& L. Montes Ramírez (Eds.), El mesolitico geométrico en la Península Ibérica. Monografias Arqueológicas 44 (pp. 343360). Zaragoza: Universidad de Zaragoza.

Aura, J. E., Jordá, J. F., Pérez, M., \& Rodrigo, M. J. (2002). The far south: The Pleistocene-Holocene transition in Nerja cave (Andalucia, Spain). Quaternary International, 93(94), 1930 .

Ballouche, A., Marinval, P., \& El Idrissi, A. (2012). Néolithisation et néolithique ancien au Maroc. In Encyclopédie berbère XXXIII (pp. 499-552). Peeters: Louvain/Paris.

Barciela González, V. (2011). El estudio de la malacofauna: Implicationes paleoambientales y antropicas. In P. Torregrosa Giménez et al. (Eds.), Benàmer (Muro d'Alcoi, Alicante): Mesolíticos y neoliticos en las tierras meridionales valencianas (pp. 229-256). València: Diputació de València.

Bar-Yosef Mayer, D. E. (2005). Archaeomalacology. Mollusks in former environments of human behaviour. Oxford: Oxbow Books.

Bernabeu Aubán, J., Molina Balaguer, L., Esquembre Bebia, M. A., Ortega, J. R., \& Boronat Soler, J. (2009). La cerámica impresa mediterránea en el origen del Neolítico de la península Ibérica? In De Méditerranée et d'ailleurs. Mélanges offerts à Jean Guilaine (pp. 83-95). Toulouse: Les Archives d'Écologie Préhistorique.

Bicho, N., Haws, J. A., \& Davis, L. G. (Eds.). (2011). Trekking the shore. Changing coastlines and the antiquity of coastal settlement. New York: Springer-Verlag.

Binder, D., Clop, X., Convertini, F., Manen, C., \& Senepart, I. (2010). Les productions céramiques du Néolithique ancien. In C. Manen, F. Convertini, D. Binder, \& I. Senepart (Eds.), Premières sociétés paysannes de Méditerranée occidentale: Structure des productions céramiques (pp. 115-129). Paris: Société Préhistorique Française, Mémoire 51.

Broich, M., Potì, A., Linstädter, J., Gibaja, J. F., Mazzucco, N., Vadillo Conesa, M., Mikdad, A., \& Weniger, G.-C. (2020). The Early and Middle Holocene lithic Industries of Ifri n'Etsedda (Eastern Rif, Morocco). African Archaeological Review. https://doi.org/10.1007/s10437-020-09377-8.

Cacho, I., Grimalt, J. O., Canals, M., Sbaffi, L., Shackleton, N. J., Schönfeld, J., \& Zahn, R. (2001). Variability of the western Mediterranean Sea surface temperature during the last 25,000 years and its connection with the Northern Hemisphere climatic changes. Paleooceanography, 16, 40-43. 
Cámalich Massieu, M. D., \& Martín Socas, D. (1999). El territorio almeriense desde los inicios de la producción hasta fines de la antigüedad. In Un modelo: La depresión de Vera y cuenca del río Almanzora. Sevilla: Junta de Andalucía, Consejería de Cultura.

Cantillo Duarte, J.J., Bernal Casasola, D, Ramos Muñoz, J. (Eds). (2014). Molusco y púrpura en contextos arqueológicos Atlántico-Mediterráneos: Nuevos datos y reflexiones en clave de proceso histórico. Actas historia y arte. Universidad Cadiz.

Carrión, J. S., Fernández, S., Jiménez-Moreno, G., Fauquette, S., Gil-Romera, G., González-Sampériz, P., \& Finlayson, C. (2010). The historical origins of aridity and vegetation degradation in southeastern Spain. Journal of Arid Environments, 74, 731-736.

Carvalho, A. F. (2008). A neolitização do Portugal meridional. Os exemplos do Maciço Calcário Estremenho e do Algarve ocidental. Faro: Universidade do Algarve.

Carvalho, A. F. (2010). La passage vers l'Atlantique: Le processus de néolithisation en Algarve (sud du Portugal). L'Anthropologie, 114, 141-178.

Coll, M., Piroddi, C., Steenbeek, J., Kaschner, K., Ben Rais Lasram, F., Aguzzi, J., et al. (2010). The biodiversity of the Mediterranean Sea: Estimates, patterns, and threats. PLoS One, 5(8), 11842.

Colonese, A. C., Mannini, M. A., Bar-Yosef Mayer, D. E., Fa, D. A., Finlayson, J. C., Lubell, D., \& Stiner, M. C. (2011). Marine mollusc exploitation in Mediterranean prehistory: An overview. Quaternary International, 239, 86-103.

Combourieu Nebout, N., Peyron, O., Dormoy, I., Desprat, S., Beaudouin, C., Kotthoff, U., \& Marret, F. (2009). Rapid climatic variability in the west Mediterranean during the last 25000 years from high resolution pollen data. Climate of the Past, 5, 503-521.

Cortés Sánchez, M., Jiménez Espejo, F. J., Simón Vallejo, M. D., Gibaja Bao, J. F., Faustino Carvalho, A., Martinez-Ruiz, F., et al. (2012). The Mesolithic-Neolithic transition in southern Iberia. Quaternary Research, 77, 221-234.

Darwin, C. (1851). A monograph on the sub-class Cirripedia, with figures of all the species. The Lepadidae; or, pedunculated cirripedes. London: The Ray Society.

Daugas, J.-P., El Idrissi, A., Ballouche, A., Marinval, P., \& Ouchaou, B. (2008). Le Néolithique ancien au Maroc septentrional: Données documentaires, sériation typochronologique et hypothèses génétiques. Bulletin de la société préhistorique française, 105(4), 787-812.

Dean, R. M., \& Carvalho, A. F. (2011). Surf and turf: The use of marine and terrestrial resources in the Early Neolithic of coastal southern Portugal. In N. F. Bicho, J. A. Haws, \& L. G. Davis (Eds.), Trekking the shore: Changing coastlines and the antiquity of coastal settlements (pp. 291-302). New York: Springer.

deMenocal, P., Ortiz, J., Guilderson, T., Adkins, J., Sarnthein, M., Baker, L., \& Yarusinsky, M. (2000). Abrupt onset and termination of the African humid period: Rapid climate responses to gradual insolation forcing. Quaternary Science Reviews, 19, 347-361.

El Hajraoui, M. A., Oudouche, H., \& Nespoulet, R. (2012). Étude des coquilles perforées découvertes à Témara. In M. A. El Hajraoui, R. Nespoulet, A. Debénath, \& H. L. Dibble (Eds.),
Préhistoire de la région de Rabat-Témara (pp. 191-199). Rabat: Royaume du Maroc.

Espinosa, F., Rivera-Ingraham, G. A., Fa, D., \& García-Gómez, J. C. (2009). Effect of human pressure on population size structures of the endangered Ferruginean limpet: Toward future management measures. Journal of Coastal Research, 25(4), 857-863.

Finlayson, C., Fa, D. A., Jiménez Espejo, F., Carrión, J. S., Finlayson, G., Giles Pacheco, F., Rodríguez Vidal, J., Sringer, C., \& Martínez Ruiz, F. (2008). Gorham's Cave, Gibraltar - the persistence of a Neanderthal population. Quaternary International, 181, 64-71.

Fletcher, W. J., Boski, T., \& Moura, D. (2007). Palynological evidence for environmental and climatic change in the lower Guadiana valley, Portugal, during the last 13000 years, The Holocene, 17, 481-494.

García Borja, P., Aura Tortosa, J. E., Bernabeu Aubán, J., \& Jordá Pardo, J. F. (2010). Nuevas perspectivas sobre la Neolitización en la Cueva de Nerja (Málaga-España): La cerámica de la sala del Vestíbulo. Zephyrus, 66, 109-132.

Garcia Borja, P., Cortell Pérez, E., Pardo Gordó, S., \& Pérez Jorda, G. (2011). Las cerámicas de la Cova de l'Or (Beniarrés, Alacant). Tipología y decoración de las colecciones del Museu d'Alcoi. Recerques del Museu d'Alcoi, 20, 71-136.

García Puchol, O., \& Aura Tortosa, J. E. (2006). El Abric de la Falguera (Alcoi, Alacant). 8,000 años de ocupación humana en la cabecera del río de Alcoi. Alcoi: Excma Diputación de Alicante.

Giannuzzi Savelli, R., Pusateri, F., Micali, P., Nofroni, I., \& Bartolini, S. (2014). Atlas of Mediterranean seashells. Palermo: Naturama.

Guilaine, J., Briois, F., Vigne, J.-D., \& Carrère, I. (2000). Découverte d'un néolithique précéramique ancien chypriote (fin 9e, début 8e millénaires cal. BC), apparenté au PPNB ancien/moyen du levant nord. Comptes Rendus de l'Académie des Sciences, Paris, Sciences de la Terre et des Planètes, 330, 75-82.

Huber, A. (2010). Compendium of bivalves. Harxheim: ConchBooks.

Hutterer, R., Mikdad, A., \& Ripken, T. E. J. (2011). Species composition and human exploitation of terrestrial gastropods from Taghit Haddouch, an Early Holocene archaeological site in NE Morocco. Archiv für Molluskenkunde, 140, 57-75.

Hutterer, R., Linstädter, J., Eiwanger, J., \& Mikdad, A. (2014). Human manipulation of terrestrial gastropods in Neolithic culture groups of NE Morocco. Quaternary International, 320, 83-91.

Idrissi, A. (2001). Le Néolithique ancien du Maroc septentrional dans son contexte régional. Ph.D. thesis. Institut National des Sciences de l'Archéologie et du Patrimoine, Rabat.

Jorda Pardo, J. F. (1982). La malacofauna de la Cueva de Nerja (II): Los elementos ornamentales. Zephyrus, 34(35), 91-98.

Kemp, B. J. (1967). Shell bracelets in Egypt. In C. B. M. McBurney (Ed.), The Haua Fteah (Cyrenaica) and the Stone Age of the south-east Mediterranean. Cambridge: The University Press.

Kuhlmann, H., Meggers, H., Freudenthal, T., \& Wefer, G. (2004). The transition of the monsoonal and the $\mathrm{N}$ Atlantic climate system off NW-Africa during the Holocene. Geophysical Research Letters, 31, L22204. 
Linstädter, J. (2004). Zum Frühneolithikum des westlichen Mittelmeerraumes. Die Keramik der Fundstelle Hassi Ouenzga. AVA-Forschungen, 9, 1-188.

Linstädter, J. (2008). The Epipaleolithic-Neolithic transition in the Mediterranean region of Northwest-Africa. Quartär, 55, 4162.

Linstädter, J. (2011). The Epipalaeolithic Neolithic transition in the Eastern Rif Mountains and the Lower Moulouya valley, Morocco. In J. F. Gibaja \& A. F. Carvalho (Eds.), Os últimos cacadores-recolectores e as primeiras comunidades produtoras do sul da Península Ibérica e do norte de Marrocos, Promotoria Monografica 15 (pp. 89-98). Faro: Universidade do Algarve.

Linstädter, J. (2016). Climate induced mobility and the missing Middle Neolithic of Morocco. In M. Reindel et al. (Eds.), Papers of the workshop: Palaeoenvironment and the development of early settlements (pp. 63-80). Rahden/Westphalia: Leidorf.

Linstädter, J., \& Kehl, M. (2012). The Holocene archaeological sequence and sedimentological processes at Ifri Oudadane, NE Morocco. Journal of Archaeological Science, 39, 33063323.

Linstädter, J., \& Wagner, G. (2013). The Early Neolithic pottery of Ifri Oudadane, NE Morocco. Qualitative and quantitative evidences. Journal of African Archaeology, 11(2), 155-196.

Linstädter, J., Medved, I., Solich, M., \& G.-Chr. Weniger (2012). Neolithisation process within the Alboran territory: Models and possible African impact. Quaternary International, 274, 219-232.

Linstädter, J., Wagner, G., Broich, M., Gibaja Bao, J. F., \& Rodríguez Rodríguez, A. (2015). Neolithic transition and lithic technology. The Epipalaeolithic and Early Neolithic assemblages of Ifri Oudadane, NE-Morocco. Quartär, 62, $155-184$.

Linstädter, J., Broich, M., \& Weninger, B. (2018). Defining the Early Neolithic of the Eastern Rif, Morocco - spatial distribution, chronological framework and impact of environmental changes. Quaternary International, 472(B), 272-282.

López Sáez, J. A., López Merino, L., Pérez Díaz, S., \& Alba Sánchez, F. (2010). Paleopaisajes de Andalucía Oriental durante la transición Mesolítico-Neolítico antiguo. In J. F. Gibaja \& A. F. Carvalho (Eds.), Os últimos ca adoresrecolectores e as primeiras comunidades productoras do sul da Península Ibérica e do norte de Marrocos (pp. 213220). Faro: Universidade do Algarve. Faculdade de Ciências humanas e sociais.

Lorenz, L. (2011). Ifri Armas - Ein Beitrag zur Erforschung des marokkanischen Frühneolithikums. Zeitschrift zur Archäologie außereuropäischer Kulturen, 3, 91-125.

Luján Navas, A. (2016). Aprovechamiento y gestión de recursos malacológicos marinos en la fachada mediterránea de la Península Ibérica durante la prehistoria reciente. Ph.D. thesis. Alicante: University of Alicante.

Luján Navas, A., Jover Maestre, J. F., \& Barciela González, V. (2014). Obtención, intercambio y consumo de recursos malacológicos marinos durante el IV y el III milenio cal $\mathrm{BC}$ entre los ríos Júcar y Segura. In J. J. Cantillo Duarte et al. (Eds.), Molusco y púrpura en contextos arqueológicos atlántico-mediterráneos: Nuevos datos y reflexiones en clave de proceso histórico, Actas historia y arte (pp. 97-106). Cadiz: Universidad Cadiz.
Manen, C., Marchand, G., \& Carvalho, A. F. (2007). Le Néolithique ancien de la péninsule Ibérique: Vers une nouvelle évaluation du mirage africain? Actes du XXVIe congrès préhistorique de France-Avignon, 2004, 133-151.

Martínez Andreu, M. (2002). La Cueva del Algarrobo (Mazarrón, Murcia). Balance de las intervenciones de 1986 a 1996. Memorias de Arqueología, 11, 45-66.

Martínez Andreu, M., \& Sánchez Gómez, J. (2006). Cueva de la Higuera (Isla Plana, Cartagena). Jornadas de Patrimonio Histórico. Intervenciones en el Patrimonio Arquitectónico, Arqueológico y Etnográfioco de la Region de Murcia, 17, 45-46.

McBurney, C. B. M. (1967). Cambridge Haua Fteah (Cyrenaica) and the Stone Age of the south-east Mediterranean. Cambridge: Cambridge University Press.

Morales, J., Pérez-Jordà, G., Pena-Chocarro, L., Zapata, L., RuízAlonso, M., López-Sáez, J. A., \& Linstädter, J. (2013). The origins of agriculture in North-West Africa: Macro-botanical remains from Epipaleolithic and Early Neolithic levels of Ifri Oudadane (Morocco). Journal of Archaeological Science, 40, 2659-2669.

Morales, J., Pérez Jordà, G., Peña-Chocarro, L., Bokbot, Y., \& Linstädter, J. (2016). The introduction of South-Western Asian domesticated plants in North-Western Africa: An archaeobotanical contribution from Neolithic Morocco. Quaternary International, 412, 96-109.

Mulazzani, S. (2013). Le capsien de Hergla (Tunisie): Culture, environnement et économie. Reports in African archaeology 4. Frankfurt: Africa Magna Verlag.

Mulazzani, S., Belhouchet, L., Salanova, L., Aouadi, N., Dridi, Y., Eddargach, W., Morales, J., Tombret, O., Zazzo, A., \& Zoughlami, J. (2016). The emergence of the Neolithic in North Africa: A new model for the Eastern Maghreb. Quaternary International, 410, 123-143.

Pasteur-Humbert, C. (1962). Les mollusques marins testacés du Maroc. I. Gastéropodes. II. Lamellibranches, Scaphopodes. Rabat: Traveau de l'Institut Scientifique Chérifien, Rabat.

Pinhasi, R., Thomas, M. G., Hofreiter, M., Currat, M., \& Burger, J. (2012). The genetic history of Europeans. Trends in Genetics, 28, 496-505.

Poppe, G. T., \& Goto, Y. (1991). European seashells. Vol. I (Polyplacophora, Caudofoveata, Solenogastra, Gastropoda). Wiesbaden: Christa Hemmen.

Poppe, G. T., \& Goto, Y. (1993). European seashells. Vol. II (Scaphopoda, Bivalvia, Cephalopoda). Wiesbaden: Christa Hemmen.

Prendergast, A., Stevens, R., O'Connell, T., Fadlalak, A., Touati, M., \& al-Mzeine, A., \& Barker, G. (2016). Changing patterns of eastern Mediterranean shellfish exploitation in the Late Glacial and Early Holocene: Oxygen isotope evidence from gastropod in Epipaleolithic to Neolithic human occupation layers at the Haua Fteah cave, Libya. Quaternary International, 407, 80-93.

Ramos Muñoz, J. R., \& Lazarich González, M. (2002). Memoria de la excavación arqueológica en el asentamiento del $V I^{\circ}$ milenio A.N.E. de "El Retamar" (Puerto Real, Cádiz). Sevilla: Consejería de Cultura, Empresa Pública de Gestión de Programas Culturales.

Reitz, E. J., \& Wing, E. S. (2008). Zooarchaeology (2nd ed.). New York: Cambridge University Press. 
Rojo Guerra, M. A. (Ed.). (2010). Zafrín: Un asentamiento del neolítico antiguo en las islas Chafarinas (Norte de África, España). Valladolid: Studia Archaeologica 96, Universidad de Valladolid.

Roski, N. (2015). Die Fauna der Ifri Oudadane. B.A. thesis. University of Cologne, Cologne.

Roski, N. (2018). Maritime fishing during the transition from the Epipaleolithic and Early Neolithic at Abri Ifri Oudadane, NE Morocco. M.A. thesis. University of Tubingen, Tubingen.

Serrand, N., Vigne, J.-D., \& Guilaine, J. (2005). Early preceramic Neolithic marine shells from Shillourokambos, Cyprus (late 9th-8th mill. cal BC): A mainly-ornamental set with similarities to mainland PPNB. In D. E. Bar-Yosef Mayer (Ed.), Archaeomalacology. Mollusks in former environments of human behavior (pp. 122-129). Oxford: Oxbow Books.

Steele, T. E., \& Álvarez Fernández, E. (2012). Restes de mollusques marins. In M. A. El Hajraoui, R. Nespoulet, A. Debénath, \& H. L. Dibble (Eds.), Préhistoire de la région de Rabat-Témara (pp. 223-227). Rabat: Royaume du Maroc.

Steele, T. E., \& Álvarez-Fernández, E. (2011). Initial investigations into the exploitation of coastal resources in North Africa during the Late Pleistocene at Grotte des Contrebandiers, Morocco. In N. F. Bicho, J. A. Haws, \& L. G. Davis (Eds.), Trekking the shore: Changing coastlines and the antiquity of coastal settlement (pp. 383-403). New York: Springer Science.

Steele, T. E., \& Klein, R. G. (2008). Intertidal shellfish use during the Middle and Later Stone Age of South Africa. Archaeofauna, 17, 63-76.
Teske, P. R., Papadopoulos, I., McQuaid, C. D., Newman, B. K., \& Barker, N. P. (2007). Climate change, genetics or human choice: Why were the shells of Mankind's earliest ornament larger in the Pleistocene than in the Holocene? PLoS One, 7, 614.

Torregrosa Giménez, P., Jover Maestre, F. J., López Seguí, E. (eds). (2011). Benàmer (Muro d'Alcoi, Alicante) Mesolíticos y neolíticos en las tierras meridionales valencianas.

World Register of Marine Species WoRMS (n.d.); www. marinespecies.org. Accessed 2013-2019.

Zamouri-Langar, N., Chouba, L., Ajjabi Chebil, L., Mrabet, R., \& El Abed, A. (2011). Les coquillages bivalves des côtes tunisiennes. Salammbô: Institut National des Sciences et Technologies de la Mer.

Zapata, L., López-Sáez, J. A., Ruiz-Alonso, M., Linstädter, J., Pérez-Jordà, G., Morales, J., Kehl, M., \& Pena-Chocarro, L. (2013). Holocene environmental change and human impact in NE Morocco: Palaeobotanical evidence from Ifri Oudadane. The Holocene, 23, 1286-1296.

Zilhão, J. (2001). Radiocarbon evidence for maritime pioneer colonization at the origins of farming in west Mediterranean Europe. PNAS, 98, 14180-14185.

Publisher's Note Springer Nature remains neutral with regard to jurisdictional claims in published maps and institutional affiliations. 